\title{
Organizing collective action: Does information and communication technology matter?
}

\author{
Cardoso, Ana; Boudreau, Marie Claude; Carvalho, João Álvaro
}

Published in:

Information and Organization

Link to article, DOI:

10.1016/j.infoandorg.2019.100256

Publication date:

2019

Document Version

Peer reviewed version

Link back to DTU Orbit

Citation $(A P A)$ :

Cardoso, A., Boudreau, M. C., \& Carvalho, J. Á. (2019). Organizing collective action: Does information and communication technology matter? Information and Organization, 29(3), [100256].

https://doi.org/10.1016/j.infoandorg.2019.100256

\section{General rights}

Copyright and moral rights for the publications made accessible in the public portal are retained by the authors and/or other copyright owners and it is a condition of accessing publications that users recognise and abide by the legal requirements associated with these rights.

- Users may download and print one copy of any publication from the public portal for the purpose of private study or research.

- You may not further distribute the material or use it for any profit-making activity or commercial gain

- You may freely distribute the URL identifying the publication in the public portal 


\title{
Organizing Collective Action: Does Information and Communication Technology Matter?
}

\begin{abstract}
In recent years, there have been significant changes in the fields of collective action and political activism. The increasing use of ICTs in social interactions has facilitated informal ways of organizing and affected the participation, emergence, and organizing of conflictual and consensual collective actions. In this study we seek to understand how the integrated use of multiple ICTs, that is the ICT ensemble, affects the organizing of consensual collective action. We investigated the ICT ensembles used by two civic movements that successfully organized large-scale consensual collective action events in two European countries. In our results, we reveal how ICT ensembles constrained and facilitated the organizing functions and requirements of collective action. The findings show that ICTs allow organizers to operate purposefully in order to organize collective action, but the extent to which they succeed in the actual concretization of collective action actually depends on their capacities and intents. Therefore, we argue that human factors (that is, their resourcefulness and agency) are greatly implicated in the success of collective action supported by ICTs. This study extends the research on impact of technology-enabled collective action by looking at the combined use of multiple ICTs and examining the rare and overlooked phenomenon of consensual collective action.
\end{abstract}

Keywords: organizing collective action; information and communication technology; ICT ensembles; mass collaboration; consensus movements; human agency

\section{Introduction}

Humans have always banded together to collaborate on the realization of collective goals that cannot be achieved individually. We associate with others to cooperate in the production of private goods or services that are tradeable and can be sold for a profit - this is what business associates do. And we also work together in the production of collective goods that, by their very own nature, cannot be privately owned and are not meant for trade (Ostrom, 2002). The acting together for the provision of these collective goods is, in essence, what collective action is about. Examples include interest groups seeking benefits, voluntary associations administering common resources, and social movements striving for civil rights (Oberschall, 2001).

People collaborating on collective goals usually are banded in formal organizations, either for profit or non-profit. Yet, the centrality of formal organizations for the provision of collective goods (collective action success) has recently been questioned (Bimber, Flanagin, \& Stohl, 2012). Many contemporary instances of collective action lack the formal organizational structure deemed necessary for coordinated action (Bennett \& Segerberg, 2012). Instead, they emerge as the result of the enhanced agency of individual entrepreneurs or small groups of organizers who leverage different information and communication technologies (ICTs), both ready-to-use and custom-developed software, to organize individual contributions and coordinate actions. Indeed, collective action nowadays takes place in a context where diverse organizational structures (e.g. formal organizations, individual entrepreneurs, informal groups) co-exist and sometimes even collaborate. Overall, this transformation means that, currently, the "fundamental solution to the challenges of collective action is not organization, but organizing" (Bimber et al., 2012, p.5; emphasis added). By organizing, we mean the ability to build the capacity to support ongoing and sustained change, which requires strategizing, development of leadership, motivating action, and engaging people (Ganz, 2002).

Organizing is different from the more well studied concept of mobilizing because mobilizing is limited to activate an existing base of support, whereas organizing begins by asking where the power needed to affect change is, and then works backwards to devise a systematic strategy to develop the resources needed to produce change (Holgate \& Simms, 2018). Thus, mobilizing is a subset of the 
more encompassing concept of organizing. There is a limited understanding of the process of organizing in non-bureaucratic organizational forms, particularly as to how social groups are able to coordinate the actions of various individuals to achieve their collective goals (O'Mahony \& Ferraro, 2007).

Our knowledge is also scant in terms of how consensual collective action (as opposed to conflictual types of collective action) does organize (Della Porta \& Diani, 2006; Michaelson, 1994; Mueller, 1992). Since these informal groups leveraging community empowerment are potential prominent players in civil society, it is important that we understand how they function and evolve, and the role that ICTs may play in their existence and success. In particular, rather than focusing on a single technology (e.g. video sharing or microblogging), we are interested in the integrated use of ICTs, that is the ICT ensembles (Scheepers \& Middleton, 2013; Lamb \& Davidson, 2005) used for the purposes of organizing consensual collective action. Such understanding is valuable to those interested on seizing, fostering, and opposing the revolutionary potential of collective action organizing.

Against this backdrop, this paper aims at explaining how the use of ICT ensembles affects the organizing of consensual collective action. This research inquires into the experiences of people who organized and participated in consensual collective action in the current technological context. We are primarily interested in ICTs as part of organizers' toolkit and as part of the environment in which participants engage in collective action. This means that this research does not focus on how a specific ICT (e.g. social networking site) is used for collective action or on how organizers make decisions as to use certain ICTs in lieu of others. Instead, our interest lies in ascertaining the ways in which the integrated use of ICTs (or ICT ensembles) interferes, positively or negatively, with the organizing of consensual collective action.

Like others (e.g. Ghobadi \& Clegg, (2015); Vaast, Safadi, Lapointe, \& Negoita, (2017)), we respond to calls for research to engage with collective phenomena beyond traditional organizationbased contexts (Majchrzak, Markus, \& Wareham, 2016; Winter, Berente, Howison, \& Butler, 2014), which has received little attention in the information systems area. Unlike those studies, however, we focus on the ICT ensembles used for the purposes of organizing consensual collective action.

We examine this issue in the context of large-scale consensual collective actions organized by two civic movements: Let's Do It in Estonia, and Project Let's Cleanup Portugal. Both of them organized, for the first time ever, a national cleaning day in the country, engaging thousands of citizens and organizations in removing tons of litter from forests and green public areas on a single day. We investigated how they leveraged a variety of ICTs, which were used as ensembles (Lamb \& Davidson, 2005; Scheepers \& Middleton, 2013), to support their organizing work.

This research contributes to the emerging literature on technology use for collective action in the information systems area (Ghobadi \& Clegg, 2015; Leong, Pan, Ractham, \& Kaewkitipong, 2015; Selander \& Jarvenpaa, 2016; Vaast et al., 2017; Zheng \& Yu, 2016). Although former research has explored use of specific ICTs in the context of emergence, participation in, and organizing of collective action, it has under-examined how exactly the integrated use of ICTs affects the organizing of collective action. Our study intends to contribute to reduce that knowledge gap by showing positive and negative effects of technology use on the organizing functions required for collective action.

The remainder of this paper has the following structure. The next section presents the theoretical background for the current study. In particular, it introduces consensual collective action and discusses how ICTs affect collective action. From that literature, we then present our research question. In Section 3, we introduce the research sites, and explain and justify the research approach. Section 4 presents the results of our study, and section 5 discusses our findings. 


\section{Theoretical Background}

\subsection{Organizing Collective Action}

Collective action is concerned with the pursuit of a collective interest outside the marketplace (Olson, 1965). It is generally understood as intentional, coordinated actions undertaken by individuals or groups who share an interest in the provision of a collective good (Marwell \& Oliver, 1993). A collective good is characterized by difficult or unfeasible excludability, which means that is difficult to prevent those who have not contributed to its provision from reaping benefits, as for example a clean city park, or a public online discussion forum of a community of interest.

Olson's theory of collective action (Olson, 1965) suggests that, in general, groups have difficulties in providing collective goods because there is a tendency to free ride. That is, a number of individuals tend to prefer to let others bear the costs of providing these goods while they can still enjoy the benefits as everyone else (due to unfeasible excludability of collective goods). Formal organizations are thus necessary because they can coordinate individual actions and protect the collective interest from the free-ride tendency. Selective incentives that induce contributions to collective goals, such as economic and social rewards, are also imperative. Olson's theory suggests that smaller groups are more successful in providing collective goods than large ones because in small groups, lack of contributions is more noticeable, interpersonal contact is more feasible, and communication is less costly. Large groups are called "latent" because they have latent capacity or power for collective action, but potential "can be realized or mobilized only with the aid of selective incentives" (Olson, 1965, p. 51).

The relative disadvantage of large groups for organizing collective action may diminish with the use of ICTs. The use of these technologies amplifies individual capacities for monitoring behaviour and for imposing selective incentives or sanctions, within both large and small groups (Lupia \& Sin, 2003). Also, according to Marwell \& Oliver (1993), group size per se is not determinant of successful collective action; it is also important to consider whether there is some "social mechanism that connects enough people who have the appropriate interests and resources to act collectively" (page 6, emphasis added). Particularly, the subset of highly interested and/or highly resourceful group members are crucial because they have a pivotal role in the preliminary phases of collective action, according to the critical mass theory of collective action (Marwell \& Oliver, 1993).

Instances of collective action that have the use of different ICTs at their core seem to "strain the explanatory capacity of traditional collective action theory", especially with respect to the role of organizations and decisions about free riding (Bimber, Flanagin, \& Stohl, 2005, p. 371). Many cases of collective action described in the literature report on successful collective action pursued largely or completely in the absence of formal organizations, or pursued by a combination of both formal and informal structures shaped in bureaucratic or network-type organizational forms (Bennett \& Segerberg, 2013). Further, individual participation in collective action emerges not only from direct requests from formal organizers, but also from an autonomous interactive process, which has ICTbased communicative and informational environments at its core (Bimber et al., 2012). As such, the decision to participate or to free ride goes beyond the rational look at the existence of separate and selective incentives and likely involves factors hitherto unconsidered by the traditional theory of collective action.

The largest obstacles to collective action efforts are communicative and organizational: connecting with interested and resourceful potential participants, motivating them to contribute, and coordinating their efforts (Bimber et al., 2005). Organizational forms that succeed at organizing collective action usually have the following functions (Bimber et al., 2005): a) means of identifying and connecting to people with relevant, potential interest in the collective good; b) means of communicating with those potential participants; and c) means of coordinating and integrating their contributions. In addition to these functions, other requirements are that organizers have enough resources 
to bear the costs of performing the functions a), b), and c), and also have means of encouraging the necessary individual contributions and hence avoid that participants free ride (Jenkins, 1983; Olson, 1965).

These aforementioned functions and requirements are thus essential for organizing collective action. In this paper, we specifically look at the use of ICTs by organizers and participants in collective action to ascertain how the integrated use of ICTs facilitates and hinders these organizing functions and requirements. But as we will see next, not all collective action initiatives are the same.

\subsection{Consensual and Conflictual Collective Action}

For the purpose of our study, a useful clarification relates to the concepts of consensual versus conflictual collective action. Consensual collective action involves participants in cooperative solutions that achieve a high degree of popular and institutional support. They do not aim at redistribution of power or changes in social structure; rather, they focus on community empowerment (Della Porta \& Diani, 2006). Conversely, conflictual collective action concerns the redistribution of power, where those less privileged emancipate to rectify their weaker position and face resistance from the elites, who seek to maintain their power status and do not identify with their claims and demands (Della Porta \& Diani, 2006).

Consensual and conflictual collective actions often materialize in movements. Movements are networks of informal interactions between multiple actors, with some degree of organization and temporal continuity, engaged in collective action with change-oriented goals on the basis of a shared collective identity (Della Porta \& Diani, 2006; Snow, Soule, \& Kriesi, 2004). The most common form is conflict movements, such as Los Indignados in Spain, the Arab Spring in the Middle East, or the recent Yellow Vests in France. Conflict movements attempt to promote institutional change in society, have clearly identified opponents, and pursue their objectives through repertoires of action that are contentious, such as protests, demonstrations, and boycotts (Snow et al., 2004; Turner \& Killian, 1964).

Alternatively, consensus movements seek different forms of change (e.g., cultural, social, economic) and involve people on the basis of solidarity issues, typically involving cooperative forms of expression that do not imply nor require the identification of specific adversaries, and face little to no organized opposition (Diani \& Bison, 2004; McCarthy \& Wolfson, 1992; Michaelson, 1994). Examples of consensus movements are the anti-poverty movement (of which Band Aid and Live Aid concerts have been part), the city twinning movement (Lofland, 1989), the so-called "southern selfhelp movements" (Michaelson, 1994), and the global movement for a cleaner planet Let's Do It! World, which is one of the cases in this research.

Consensus movements have certain peculiarities that are not found in conflict movements, namely: they organize themselves around the co-optation of human and material resources, that is, they leverage civic and state infrastructural resources (McCarthy \& Wolfson, 1992); they attract people who favor a non-political and noncontroversial approach to activism, and often do not require heavy commitment or intense association from members (Schwartz \& Paul, 1992). These structural characteristics create strategic rigidity and thus limit consensus movement's ability to adopt new goals and tactics. Often, these movements have difficulties in sustaining the membership they initially attract, and when consensus declines, co-optability also declines (Schwartz \& Paul, 1992).

The current main theoretical paradigms of social movements research (i.e., the resource mobilization theory and the political opportunity structures in North America, and the new social movements in Europe) have almost exclusively investigated movements with oppositional or adversarial stances (i.e., conflict movements). Unfortunately, this has resulted in the common and nearly interchangeable use of the terms "conflict movement" and "social movement" (Michaelson, 1994). This 
preference for conflict movements makes a disservice to this research area, as it limits its relevance to a specific type of movement only. Movements that seek other (non-institutional) types of change, where sustained collective action does not have a conflictual element, are largely not captured nor explained under the existing paradigms (Jenkins, 1983; Mueller, 1992).

Despite the scant scholarship on consensus movements, the investigation of empirical instances of consensual collective action contributes to a better understanding of social movements phenomena in general, and has been encouraged (Della Porta \& Diani, 2006). For example, the study of these movements can improve the understanding of the linkage between micro and macro level processes of collective action. Micro level processes, such as individual participation and recruitment, have been treated as simplifying assumptions by the resource mobilization theory, where collective interests are assumed to exist prior to mobilization, instead of being socially construed (Jenkins, 1983). However, these micro processes are at the core of how consensus movements are constituted (e.g. movement goals are created through social interaction) and hence their study can inform the understanding of the micro-macro level interactions. Accordingly, in this research, we elect to specifically focus on consensus movements.

\subsection{Collective Action and Information and Communication Technologies}

Contemporary collective action takes place against the backdrop of information and communication technologies (ICTs) that include ubiquitous computing, mobile devices, and online social networks. These types of ICTs are considered the enabler of the "third platform for business innovation" by the International Data Corporation (IDC) (Gens, 2013). Besides the benefits to planning and execution of work facilitated by networked personal computers (IDC's second platform), the technologies underlying the third platform enable new forms of involvement and participation of individuals in all sorts of human endeavours, including collective action (e.g., Römmele, 2003; Wang \& Zhang, 2012).

The ICTs typically used in collective action situations mainly involve messaging and information sharing services. Examples include e-mail and other messaging services, blogs, VoIP services, websites, and social media platforms. Personal productivity applications (word processing, spreadsheets, presentations, databases, agendas), often used via cloud-based services, are also inescapable tools for the needs of organizers of collective action. The use of mobile devices is a growing tendency (Anduiza, Cristancho, \& Sabucedo, 2014; George \& Leidner, 2018; Pierskalla \& Hollenbach, 2013), and indeed smartphones and tablets facilitate a wide range of apps that provide functionality and access to information services (e.g., maps, traffic, weather) that can be relevant for the objectives of specific types of collective action. These applications go beyond the communication functionalities, to address planning, optimization, and other organizing aspects.

There is extensive literature on the impact of use of ICTs in collective action. Our analysis of this literature (summarized in Annex 1) reveals that previous research has taken different foci, namely: emergence of collective action, participation in collective action, and organizing of collective action, as discussed below.

The focus on emergence of collective action has been investigated in the context of ICT-powered informal groups. ICTs improve the flow of information, and reduce the cost and increase the speed of community involvement, which leads to the emergence of collective action (Hampton, 2003). Resources can be shared within a community, without the need for physical co-location and thus reduce costs (Coopman, 2011). ICTs also enable the development of different types of power within a community and transform it from a follower to a driver of social movement (Tye, Leong, Tan, Tan, \& Khoo, 2018). In crisis response situations, ICTs empowers communities and enable them to collectively participate, to attain shared identification, and to attain collaborative control (Tye et al., 2018). However, outcomes are uncertain as the ICT-based conditions for emergence of collective 
action are subject to both encouraging (gathering support and protection of anonymity) and inhibiting (surveillance, internet filtering) forces, which may result in decline of collective action (Ghobadi \& Clegg, 2015).

As to participation in collective action, it has been studied in the context of both formal organizations and informal organizing structures. The use of ICTs by formal collective action organizations contributes to the enactment of different participatory styles across their members (Bimber et al., 2012), removes constraints of space and time for communicating with members, and lowers the costs of members' participation (Klein, 1999). For informal organizing structures, ICT-based communication contributes to establishing collective identities (Harlow \& Harp, 2012; Lombardo, Zakus, \& Skinner, 2002; Lomicky \& Hogg, 2010; Milan, 2015), and also to reduce the costs of joining any one group (Vasi, 2006), allowing for this to happen faster (McGrath, Elbanna, Hercheui, Panagiotopoulos, \& Saad, 2012), and beyond geographical limitations (Huang \& Sun, 2014). This online participation often translates to offline collective action (Harlow \& Harp, 2012).

Literature that focused on the organizing of collective action also reveals the role of ICTs in lowering the costs and reducing the need for co-presence (Earl \& Kimport, 2011). This literature indicates that ICTs reduce the costs of communication (Lin \& Dutton, 2003a) and afford broad and fast communications (George \& Leidner, 2018). However, the use of different ICTs can lead to overall higher communication costs (Nielsen, 2009) and dispersion of material and resources (Micó \& Casero-Ripollés, 2014). The use of ICTs also reshapes access and reconfigures networks of communication (Lin \& Dutton, 2003a), re-establishes the power of individual constituents (Hara \& Youngmin, 2007), and affects the emancipatory process of oppressed groups by enabling awareness and solutions (Young, 2017). Although this literature has identified effects of ICTs on different aspects of organizing (costs, communication), it is still not clear how this happens. For example, it sounds logical and reasonable that the use of ICTs changes the costs of organizing, but we still do not know what is it that ICTs facilitate or hinder that makes the costs of organizing change.

In addition to these three foci, the analysis of the literature on use of ICTs and collective action reveals that, with a few exceptions (e.g. Leong et al. (2015) and Zheng \& Yu (2016)), the majority of instances of collective action we reviewed had an oppositional stance, and hence come closer to the conflictual type, rather than consensual type, of collective action. The fact that little attention has been paid to consensual collective action does not mean that instances of this kind of collective action are not as relevant or consequential. Actually, the scarcity of cases points to the fact that consensual collective actions struggle to avoid co-opting by institutionalized actors, such as governments and mass media (McCarthy \& Wolfson, 1992).

Moreover, this literature considered the use of a single ICT (e.g. microblogging, video-sharing, website) or a small subset of ICTs (social media), and has not looked into the use of ICT ensembles (Lamb \& Davidson, 2005; Scheepers \& Middleton, 2013) in the process of organizing collective action. Yet, nowadays not only the ICTs used for collective action include an array of different technologies (George \& Leidner, 2018), but in practice people engaged in the organizing of collective action combine their use in ICT ensembles to achieve their objective. The focus on a single ICT fails to seize the complexity of combining ICTs (Watson-Manheim \& Bélanger, 2007), and we think may lead to narrow conceptualizations of the IT artifact (Majchrzak et al., 2016). As such, by looking at the whole picture in terms of ICTs used, it is possible to have a richer account of the phenomenon of technology-enabled collective action.

In this study, we address the aforementioned gaps in regards to the use of ICTs in collective action. More specifically, we seek to deal with the following issues: lack of understanding about how different facets of an organizing effort are affected by ICTs; minimal attention paid to consensual collective action; lack of consideration of ICT ensembles (rather than single ICTs). This is reflected in 
our research question: how does the use of ICT ensembles affect the organizing of consensual collective action?

To answer this research question, we engaged in an inquiry of consensual movements that used ICTs in the organizing of large-scale collective action events. We focused on movements that leveraged multiple ICTs, that were consensual in nature, and for which we could get deeper insight in terms of their organizing. Using an interpretive in-depth case study approach, we investigated two consensus movements that organized country-scale collective action events, which involved thousands of participants and had a great societal impact. These case studies constituted a theory-rich perspective exploration of the organizing of collective action that enabled the identification of the facilitating and hindering roles of ICTs.

\section{Method}

There are limited possibilities for collecting empirical data about use of ICTs in the organizing of collective action because the phenomenon is not reproducible in laboratory and can only be inquired in its naturalistic setting, when (and if) it occurs. Given the aim of this research, a method that values both contextual consideration and participants' views on their experiences was deemed appropriate. Accordingly, we elected to conduct an in-depth, interpretive, multiple case study. This method is well suited to answering "how" questions (Klein \& Myers, 1999; Walsham, 1995), such as the one at the core of our research.

\subsection{Research sites}

The kind of collective action examined in this research is consensual collective action, particularly in the form of a movement. In this kind of civic movement, collective goods are produced through cooperative efforts that do not imply the identification of specific adversaries, do not require alterations in social structure, and focus on community empowerment rather than conflictual strategies (Della Porta \& Diani, 2006). By focusing on this particular kind of collective action phenomenon, we can set aside the issues of power distribution, grievances, and societal transformation that are at the core of traditional (conflict-based) social movements, and focus instead on the "building together" mantra that defines consensual collective action.

The cases examined were the civic movements Let's Do It (LDI), from Estonia, and Project Let's Cleanup Portugal (PLP). These civic movements were distinct from one another, occurring at different time periods and locations. But these civic movements were also similar in other ways. Both organized collective action events, which involved thousands of people in their respective countries, to tackle environmental and social problems insufficiently addressed by the existing policies and governing structures. Each movement led to the first-ever organized national cleaning day in each country (2008 in Estonia, and 2010 in Portugal), in which people came together to remove tons of litter illegally dumped in forests and green spaces.

Organizers of these collective action events leveraged a variety of ICTs, both ready-to-use and custom-developed software, and devices such as computers, mobile phones, GPS, and digital cameras. These ICTs were used in combination, that is, as ensembles (Lamb \& Davidson, 2005; Scheepers \& Middleton, 2013), and in complement to offline activities. In addition, organizers exploited a hybrid media system (Chadwick, 2013) combining traditional media (newspapers, radio, television) and ICT-based media (website, mailing lists, and social media) to communicate with their intended audience. The organizing of these mass-scale events, particularly in terms of their associated ICT usage, is the focus of this research.

Both LDI and PLP combined characteristics of social entrepreneurship and social movements. On the one hand, these movements - just like social entrepreneurs - implemented solutions to neglected societal problems, which bring about positive value spillovers (Santos, 2012). On the other hand, PLP and LDI used tactics that are typically found in social conflict movement's repertoires (e.g. 
mass mobilization, campaigns). However, unlike conflict-oriented movements, PLP and LDI engaged participants in working together on what they perceived had to change in their community.

This amalgamation of characteristics results in a unique kind of consensus movement wherein power struggles are set aside, in favour of a more constructive approach, which involves cooperating with other stakeholders such as governing elites. As such, our cases, PLP and LDI, do not fit neatly in Lofland's (1993, p. 52) depiction of consensus movements as "timid politics", "derailed dissent", or "disguised rebellions of timid rebels"; rather, we argue, they represent a novel variation of this phenomenon and therefore their study has revelatory potential.

The reasons for selecting these cases were the following. The PLP case presented us with a unique opportunity to study this phenomenon because it occurred in Portugal, where two of the authors of this article originated. The case was interesting for two different reasons. On the one hand, it addresses environmental-related issues, whose importance has only increased. On the other hand, the situation emerged as intriguing because it involves the use of ICTs in a context radically different from the one normally explored in teaching and research in the information systems field. As to the LDI case, it was selected for similarity and to add richness and depth to the emergent findings of PLP. With two cases, we were able to compare and contrast both studies.

\subsection{Data Collection}

The interpretive tradition calls for data collection techniques that facilitate the examination of a phenomenon in its naturalistic setting and the interpretation of the world from a subjective perspective. Hence, we used semi-structured interviews as our main instrument for data collection. We combined interviews with a diverse collection of documentation, which was gathered from different online sources for both cases. This data was useful to build a general understanding of the cases prior to interviewing.

The cases examined in this study were widely discussed online and in mass media and therefore a rich digital information trail was available. We collected minutes of meetings, written reports of events by bloggers, manuals and tutorials created by volunteers, posters, flyers and presentations used for promoting the cleaning event, online forum threads, news clippings, interviews and reportages appearing in newspapers, national television and radio. The collection of archival data amounted to 150 files, in text, audio, and video formats. We show an overview of the interviews' dataset used in this study in Table 1, and in Annex 2 we provide a non-exhaustive list of online sources about each case.

\begin{tabular}{|l|l|l|}
\hline & LDI case & PLP Case \\
\hline Number of interviewees & 20 & 42 \\
\hline Language & English & Portuguese \\
\hline Interview contact & $\begin{array}{l}\text { In person: } 5 \\
\text { Over Skype: } 15\end{array}$ & $\begin{array}{l}\text { In person: } 40 \\
\text { Over Skype: } 2\end{array}$ \\
\hline Recording technique & $\begin{array}{l}\text { Audio only: } 11 \\
\text { Audio and video: } 9\end{array}$ & $\begin{array}{l}\text { Audio only: } 40 \\
\text { Audio and video: } 2\end{array}$ \\
\hline Length of interviews & $\begin{array}{l}\text { Average: } 43 \text { min } \\
\text { Minimum: } 29 \text { min } \\
\text { Maximum: } 97 \text { min }\end{array}$ & $\begin{array}{l}\text { Average: } 55 \text { min } \\
\text { Minimum: } 22 \text { min } \\
\text { Maximum: } 112 \text { min }\end{array}$ \\
\hline Period of interviews & $\begin{array}{l}\text { February to April } 2013 \\
\text { July to October } 2013\end{array}$ & $\begin{array}{l}\text { June to October } 2012 \\
\text { March to June } 2013\end{array}$ \\
\hline
\end{tabular}

Table 1: Overview of interviews dataset 
The data collection started with the PLP case. We requested the help of a civic association named AMO Portugal, which had bequeathed the participants base of the civic movement PLP. AMO Portugal agreed to include information about this study in their electronic newsletter, inviting their readers to contact the first author if interested. It followed that 56 individuals volunteered to discuss their involvement in PLP with us. Of these 56 potential participants, 24 were selected and agreed to an in-person interview. Afterward, we used a snowball approach (Biernacki \& Waldorf, 1981) to identify additional respondents, where each interviewee was asked to suggest other knowledgeable participants or, in some cases, a specific individual they had named during the interview - either because that person might augment their statement or might have a different, or perhaps contradictory, account. This allowed us to interview 18 additional PLP participants. We provide, in Annex 3, demographic details of the participants, together with the interview instruments.

As we collected data on the PLP case, we realized that this civic movement had drawn inspiration and guidance from the Estonian movement Let's Do It (LDI). Our first impression on this movement, informed by secondary data available online, was that although LDI and PLP shared some commonalities and had achieved similar results, they also had distinct features. Hence, we decided to include this second case in our data set, to provide greater richness and support to our research question. We had no previous connections in Estonia, but arranged a call through Skype with someone on the core team of LDI. A few months later, the LDI core team agreed to formally participate in our study.

To interview additional participants associated with the LDI case, the first author attended the Clean World Conference, a three-day gathering for the countries involved in the global movement Let's Do It! World. The conference took place in Tallinn, in 2013, and had delegates from most of the 96 countries that had already prepared collective action events in their countries. Therefore, it was a great opportunity to meet and learn about different forms of organized collective action events that were going on in the world. During this conference, the first author conducted 5 inperson interviews, and arranged for an additional 15 interviews to be conducted over Skype in the following weeks.

\subsection{Data Analysis}

The data gathered for this study was examined in three stages. We used qualitative data analysis software (Researchware) for the coding and data analysis. The first stage consisted of open-ended discovery of archival data and documentation (i.e. the digital trail of the cases), wherein the main objective was to capture the main themes and build a general understanding of the cases prior to collecting primary data. The main output from this stage were case summaries. These summaries were a useful starting point for developing interview guides and preparing case discussions. An initial codebook was created in this stage (see Annex 4, stage 1), through the sorting of data with descriptive codes, constant comparison, and incremental revision with discarding and re-coding of text segments.

The second stage was intermediate analysis, and involved grouping, ranking, and sorting codes, summarizing and ordering case data, and devising concept maps. The main goal for this stage was to examine the cases' process data. In other words, we wanted to understand how things evolved over time and why they happened in a certain way (Langley, 1999). Particularly, the goal was to make sense of the stories we had heard about national scale cleaning events, and the people and ICTs involved in these activities. This stage analysis built on the preceding work and incorporated interview data. We worked with the existing codebook and created groups of codes by clustering similar or related codes under a common banner, that is, a category (see Annex 4, stage 2). In order to better understand the flow of events over time, we worked with event-listing matrices (Miles \& Huberman, 1994) and concept maps. 
The third stage of data analysis was focussed analysis, and involved another round of coding and cross case comparison. The objective of this stage was to generate meaning and draw conclusions from a selected subset of data, specifically from data segments about how ICTs were used in the organizing of PLP and LDI's collective action. Hence, the coding in this stage was selective. First, we coded only the text segments that were specific about the use of some ICTs (see, in Annex 5, a complete list of ICTs used with illustrative quotations from both cases). Next, we coded selectively only the segments that were about "something" that had been facilitated or constrained by the use of ICTs, and we added the prefix "facilitated" or "hindered" to codes. Subsequently, we focussed on finding commonalities among these codes by identifying a more abstractly defined class that would allow us to cluster codes based on their affinity. The categories used for clustering emerged from the interplay of theory and data (Klein \& Myers, 1999), mainly from the classification of functions associated with organizing collective action, as laid by Bimber et al., (2005) and Flanagin, Stohl, \& Bimber (2006), which we discussed in section 2.1. This led to the codes shown in Annex 4, phase 3.

\section{Findings}

\subsection{Case Let's Do It}

Let's Do It (LDI) was the civic movement that pioneered the idea of organizing one-day countryscale events to cleanup littered forests. In 2008, it rallied 40,000 volunteer citizens in Estonia to clean up, in a single day, the entire country. The success of this civic action propelled the movement into a global quest named Let's Do It! World, which started in 2012 and has brought together more than 100 countries and about 15 million people ${ }^{1}$ to remove waste inappropriately dumped in forests and green spaces around the world. The data collected and examined in this study spans the period of 2007 to 2013. This section describes the unfolding of Let's Do It! and Let's Do It! World.

\section{Teeme Ära: $2007-2009$}

In the Summer of 2007, a group of Estonian friends got together and discussed the problem of littered forests in their country. They decided to tackle the problem through a hands-on, do-it-yourself approach and started to brainstorm ideas on how to organize a massive cleanup. They named their project as "Teeme Ära", , and devised the slogan "Let's clean up Estonia in one day!"

An estimate of how much garbage existed in the forests was necessary in order to assess the work force and machinery necessary to dispose of it. Garbage estimation was done through volunteered geographic observation (Goodchild, 2007). This consisted of the systematic observation of the country's territory, using GPS devices to obtain the coordinates of the dumpsites, and subsequently uploading the location data, together with the estimation of the volume of garbage, into an online map of "garbage points". To conduct this task, Teeme Ära established partnerships with companies that provided equipment (mobile phones), mobile Internet connection, and mobile phone software to facilitate the mapping process. Teeme Ära also enlisted mapping volunteers recruited from outdoor sports and hobby communities (e.g., bikers, geocachers, and trekkers). Also helping, a partnership with the Estonian Army was established, within which the Army integrated a mapping exercise in their training activities.

The garbage estimation exercise pointed to the need of a workforce of around 50,000 persons to clean up the litter locations mapped, and hence a communication campaign was put in place in order to mobilize citizens for the cleanup event. In addition to traditional media (e.g., leaflets, posters, etc.), campaigning was pursued via online media such as emails, blogging, bulletin boards, online forums, and Teeme Ära's website. Another strategy related to communication and public relations was the involvement of public personalities from different spheres of life, including arts, drama, and

\footnotetext{
${ }^{1}$ These are numbers from 2013, when we finalized data collection. Current numbers (March 2019) are 169 countries and 36 million volunteers.

${ }^{2}$ The translation of "Teeme Ära" to English is "Let's Do It"
} 
sports. The government also endorsed the project and provided a grant for the payment of garbage disposal fees. Numerous partnerships established with private companies provided transportation services and cleaning supplies. The project was framed as a movement of citizens, apolitical, and informal. Organizers (the initial group of five plus a few of their friends) drew on Estonia's tradition of collective work days, known as "bee" events, to operationalize the idea of the cleanup day (Pikner \& Jauhiainen, 2014).

The registration for the event was done via an online form and required that at least three people enlisted as a group. This was an intentional criterion that aimed at reinforcing the commitment of participants through peer pressure within groups. Behind the registration process, there was a team of volunteers answering questions and issuing informative emails about the event, such as the location of the gathering place, safety instructions, working manual, and useful phone numbers. In the morning of the cleanup day, mobile phone messages were automatically sent to the participants with reminders of safety instructions and location of gathering places.

The logistics of the cleaning event were supported by software developed for that end. A logistics system was built on the idea that the task of cleaning up garbage basically involved moving the garbage lying in thousands of places in the forest into a reduced number of collection places, so-called "flag stations", where large-scale sorting of waste could be done. Hence, the software revolved around the calculation of the optimal number and location of those flag stations, which was done through a clustering algorithm and a vector map of the roads' network. The garbage points identified during the garbage mapping exercise were then assigned to the nearest flag station. The logistics software also calculated the optimal number of persons for each flag station. These calculations were integrated with the registration form, and consequently new registrations were not allowed for the flag stations that had exceeded the number of optimal volunteers.

On the cleanup day (May 2008), volunteers met at their previously assigned locations where they collected cleaning supplies (trash bags, gloves) and tools. Next, they went to the garbage points assigned to collect the garbage in bags, and then dropped these bags at the flag stations. Later, trucks carried all waste to landfill and recycling facilities. A little over forty thousand persons participated in the cleaning event (3\% of Estonia's population) and more than 10,000 tons of garbage were removed from the forests in just five hours.

\section{Let's Do It! World: 2009 - 2013}

After the cleaning event, the founding team of Teeme Ära engaged in organizing other large-scale events in Estonia. For example, in 2009, they organized the event My Estonia, depicted as a oneday think tank in which 10,000 persons came together, in different cities, to brainstorm ideas and dream about the future of Estonia. Later, in 2011, they partnered with Food Bank in Estonia and organized a fund raising campaign with the goal of collecting Estonian Kroon coins that were going to be substituted by Euro currency, given Estonia's joining of the European Economic and Monetary Union.

Since 2012, on the first Saturday of May, "The Day of Civil Actions" takes place. It consists of collective actions that can be organized by any citizen, group of citizens, or organization, in order to benefit the community and contribute to common good. Examples of civil actions that have taken place include repairing and upgrading a playground, and painting local public schools. In 2013, "The Day of Civil Actions" involved 40,000 volunteers in 1,522 different civic actions that took place all over Estonia.

The founding team also became involved in organizing large-scale collective action events beyond Estonian borders. In 2009, they released a 5-minute video in YouTube about the Estonian cleaning event, and they started receiving emails from people around the world asking questions about how to organize a cleaning event. To share their experience, the team organized the first international LDI conference in January 2010, which was attended by many of the countries that went on to suc- 
cessfully organize their own cleaning event. In 2012, the global movement Let's Do It! World was officially born with the mission to remove illegal and health-endangering dumpsites from the entire planet. The network of countries affiliated with Let's Do It! World is continuously expanding, as more and more countries have succeed in organizing large-scale cleanups of illegal dumpsites.

The organizational structure of Let's Do It! World consists of a network of country teams that have done at least one organized cleanup of dumpsites in their countries, and a core team based in Estonia. The core team acts in a supportive role by handling communication and public relations at the global level, by providing technical support, by organizing regional and international conferences to encourage knowledge sharing, and by maintaining the world waste map ${ }^{3}$.

Table 1 of Annex 6 summarizes the LDI case, highlighting a phase-ordered list of the main events underlying its activities along with the ICTs used to perform these activities. The developmental phases 1 to 4 concern the organization of the countrywide cleanup event, which precede the constitution and maintenance of the global movement LDI World (phase 5).

\subsection{Case Project Let's Cleanup Portugal}

The success of Teeme Ära in 2008, in Estonia, galvanized a group of friends in Portugal to organize a similar cleaning event in Portugal. Project Let's Cleanup Portugal (PLP) presented itself as an independent civic movement of volunteer citizens involved in the cleanup of their country on a single day. They specifically requested monetary donations not to be made, as they wanted to preserve their independence and transparency and thus accepted only in-kind donations of goods, services and labor. The data collected and examined in this study covers the period of 2009 to 2013.

\section{Let's Cleanup Portugal: 2009 - 2010}

In July 2009, a group of three friends, inspired by the YouTube video posted by the Estonians, founded "Projecto Limpar Portugal"4 (PLP). The goal of PLP was to rally the Portuguese population to a one-day countrywide cleaning event that was named "Day L". Through email, the group enticed friends and acquaintances to join a community website they had created on the Ning platform. Two weeks after launched, over 4,000 individuals had registered; on the eve of "Day L", there were over 35,000 .

A so-called "national coordination team" oversaw the coordination of PLP at the national level. This team included the three founders, coordinators of district areas, and experts for the environmental, legal, and technological issues. The national coordination team devised guidelines about how to organize the cleaning event, and published these on the Ning platform. These guidelines established the common ground for the work of the local level teams (in municipalities) and ensured that the movement had coherence at national level. As mentioned earlier, a key principle was that only in-kind donations and partnerships would be accepted (no financial aid would be received).

Donations included tools, bags and gloves for collecting trash, gratuitous use of technical equipment, trucks and tractors, gratuitous transportation services for volunteers, gratuitous insurance for participants, and volunteer workforce. PLP partnered with public and private schools, Scouts groups, civil associations, the military, the civil protection, private companies, municipalities, and parishes. In addition, organizers of PLP sought the collaboration and involvement of various communities related to outdoors activities in forests, namely the online forums of all-terrain vehicle owners, cycling forums, and the growing online community of geocachers. Local mass media, such as radio and newspapers, helped promoting the project locally, and the project also drew attention of nation-

\footnotetext{
${ }^{3}$ The world waste map is a virtual map, generated through volunteered geographic observation, with the location of dumpsites around the world. Nowadays, it can be accessed via an app, as explained in LDI website:

https://www.letsdoitworld.org/worldwasteplatform/

${ }^{4}$ The translation to English is Project Let's Cleanup Portugal
} 
al mass media, especially when the president of Portugal endorsed the project and became its honorary sponsor.

For the discovery and characterization of dumpsites, PLP initially explored software services that allowed them to pinpoint places in Internet-based maps, such as Wikimapia or Wikiloc. However, it became clear that neither addressed the project's needs in terms of mapping. The developers of 3rdBlock, a web-based geo-mapping software based on the Bing Maps API, then approached the national coordination team via the Ning community website and offered to collaborate. 3rdBlock had already developed a web-based interface that allowed users to pinpoint places of interest in an Internet map and were eager to test their prototype. PLP thus adopted that technology for mapping the dumpsites.

On Day L, despite the bad weather, more than 100,000 persons (about 1\% of Portuguese population) participated in the cleaning event and, by the end of the day, more than 50,000 tons of illegally dumped garbage were removed from the forests.

\section{AMO Portugal: 2010 - 2013}

Following the cleaning event in March 2010, the municipal teams of PLP dissolved because they had formed with the single objective of organizing the cleaning event. Some discussion about what to do next ensued, in the community website. It did not seem reasonable to squander the social and organizational capital that had been built, and in July 2010, some members of the national coordination team founded an association named AMO Portugal that works under the same principles that guided the organization of the cleaning event.

AMO Portugal is an atypical non-governmental organization. Its bylaws state that the association aims at promoting national scale events through the involvement of volunteers and partnering with public, private, and non-profit organizations, at no pecuniary advantage. Further, the association has no employees, operates only with volunteer staff, and cannot own financial assets or any kind of patrimony. Its only declared assets are the creativity, know-how, and the ability to mobilize volunteers when necessary. From 2010 onwards, this association has organized other civic actions to involve citizens for environmental causes and, although these sequel events did not sustain the bequeathed volunteer base from PLP, they succeeded in keeping the spirit of entrepreneurial citizenship alive.

The use of ICTs within AMO Portugal did not generate identical opportunities for debate, discussion, and engagement of participants as it did for PLP. After the cleaning event, the PLP community website gradually lost vitality, and because the platform where it was hosted started to charge a service fee, organizers decided to deactivate it. Consequently, the official website of AMO Portugal and email became the main media of interaction with participants, and communication became focussed on reporting and disclosing information about local collective actions being organized.

Table 2 of Annex 6 summarizes the PLP case, highlighting a phase-ordered list of the main events underlying its activities along with the ICTs used to perform these activities. As can be seen, the developmental phases of PLP case were similar but not entirely aligned with those from the LDI case. For the purpose of comparability between the cases, we added a phase zero for PLP case, which corresponds to the initial stage of diffusion of the idea of the cleanup day project and the development of a decentralized organizing structure, with the local teams (municipal level) as core organizing structures. Also, we collapsed the phases of problem sensing and building support because, unlike in LDI case, there was not a phase with almost exclusively events related to mapping and collection of information about dumpsites.

\subsection{Analysis: aspects of collective action organizing associated with the use of ICTs}

In order to detect any patterns in use of ICTs, we looked into what technologies were used in different developmental phases of both cases. Table 3 of Annex 6 shows a table with the ICTs used in 
each phase, in which we can see that the following technologies were used in the same developmental phase by both cases: email, location tracking technology, internet marketing, mailing list, mobile phone software, registration form, skype, social networking site, waste map, and website. This can possibly tell us about a set of ICTs that are core to the organizing of this kind of collective action events.

Some of these technologies are more related with communication tasks (email, internet marketing, mailing list, social networking site, skype, and website), while the others appear to be more relevant for collecting the necessary information for planning of collective action events and for coordinating individual contributions (e.g. mobile phone software, registration form, waste map). We can also see from Annex 6 that email and website were the technologies used most of the time by both cases, that is, these ICTs were used in almost all phases. In PLP case, the community website was also used in most of the phases, except phase 5.

As explained in section 3.3. about the data analysis, the third stage of analysis of cases' data resulted in the clustering of codes in five high-level categories (or themes) that represent functions and requirements essential for organizing collective action, which are associated with the use of ICTs. These categories are: communication, connectivity, coordination, legitimacy, and organizing costs. The remainder of this section now drills into each of these categories to explain how the use of ICTs affected these functions and requirements of organizing collective action in both cases.

\section{Communication}

In PLP and LDI cases, communication was a core activity in the organizing of collective action events. With respect to the importance of communication in the context of organizing a collective action, an LDI interviewee conveyed: I think communication in this kind of organizations is very important because they cannot survive without explaining what they are doing and why it's important. It's actually through communication that they sell what they are doing. Take for example the cleanups: we are doing something for the world, but for that to be understood and to be supported we have to explain why we are doing it and how people can help us. Communication influences individuals' decision to engage in collective action, especially if the content of what is communicated emphasizes individual responsibility and collective benefits (Bolsen, Druckman, \& Cook, 2014).

Overall, the empirical data examined in our study points to communication, within the organizing of collective action, associated with facilitated dissemination of information, facilitated group brainstorming, facilitated reporting, and hindered focus. We show illustrative quotations from the cases (LDI and PLP) in Table 2, with ICTs in bold indicating that they were used in both cases. Table 1 of Annex 7 cross-references these ICTs and codes for the communication aspect.

\begin{tabular}{|l|l|l|}
\hline \multicolumn{2}{|c|}{ Category: Communication } \\
\hline Sub-categories & Definition & Illustrative quotation \\
\hline $\begin{array}{l}\text { Facilitates dissemination of infor- } \\
\text { mation }\end{array}$ & $\begin{array}{l}\text { Spreading infor- } \\
\text { mation widely, to } \\
\text { participants, partners } \\
\text { and other public } \\
\text { ICTs: blog, community website, not just about the cleaning, but is also about } \\
\text { email, internet marketing, mail- } \\
\text { ing list, social networking site, } \\
\text { website }\end{array}$ & $\begin{array}{l}\text { is important when we talk about IT and the marketing } \\
\text { channels related to the Internet (LDI case, organizer) }\end{array}$ \\
\hline $\begin{array}{l}\text { Facilitates brainstorming } \\
\text { ICTs: community website }\end{array}$ & $\begin{array}{l}\text { Collective production } \\
\text { of ideas and solutions } \\
\text { to problems or diffi- } \\
\text { culties }\end{array}$ & $\begin{array}{l}\text { We tried to find the consensus between those differ- } \\
\text { ent ideas in Ning [community website]. There was a } \\
\text { lot of side discussion... so we had to remind people } \\
\text { what our final goal was, to keep things going (PLP } \\
\text { case, organizer) }\end{array}$ \\
\hline
\end{tabular}




\begin{tabular}{|l|l|l|}
\hline $\begin{array}{l}\text { Facilitates reporting } \\
\text { ICTs: community website, email, } \\
\text { internet forum, intranet, mailing } \\
\text { list, mobile phone software, skype }\end{array}$ & $\begin{array}{l}\text { To give an account } \\
\text { about some action or } \\
\text { event to others (e.g. } \\
\text { progress of offline } \\
\text { work) }\end{array}$ & $\begin{array}{l}\text { I was in touch with skype and emails, at least every } \\
\text { week. I was kind of reporting to LDI about the re- } \\
\text { sources we could use... basically exchanges about } \\
\text { how we can do it, what we need to do (LDI case, col- } \\
\text { laborator) }\end{array}$ \\
\hline \hline Hinders focus & $\begin{array}{l}\text { Reducing the ability } \\
\text { to concentrate atten- } \\
\text { tion on the essential } \\
\text { issues that are of im- } \\
\text { portance for a certain } \\
\text { objective }\end{array}$ & $\begin{array}{l}\text { I think Ning [community website] is not constructive, } \\
\text { then someone writes on top of that, and so on... then } \\
\text { the issue that is relevant is already gone, it becomes } \\
\text { invisible in the flood of comments (PLP case, collab- } \\
\text { orator) }\end{array}$ \\
\hline
\end{tabular}

Table 2: How the use of ICTs affects communication, within collective action organizing (ICTs in bold indicates use in both cases)

Internet marketing, mailing list, social networking site, and website are, for both cases, the specific ICTs associated with the sub-category facilitates dissemination of information. This shows that technologies with a broadcasting function can have this facilitator role of dissemination for external communication outside the boundaries of organizing teams. Mailing lists were used by LDI since the Teeme Ära project, and are still very important for disseminating news about the global team and the network of country teams, but social media was only used in the phase of internationalization of LDI.

In PLP case, email, blog, and the community website were used for dissemination as well. The community website was instrumental in keeping participants informed about the progress of municipal teams and in getting participants involved and engaged during the preparations of the cleaning event, as a PLP interviewee explained: At that time, we had Ning [community website], in which each municipality had a page, and this facilitated a lot the dialogue with participants, because they could write messages there and then we responded to these messages. It also allowed everyone to follow what the municipal groups were doing because everyone had access to all the pages and so everything was visible... So, basically Ning [the community website] facilitated a lot this kind of interaction.

The sub-category facilitates reporting is, in both cases, linked with technologies for direct one-toone communication, such as email and mobile phone software (conventional way), but is also linked with the less conventional way or reporting one-to-many. The community website and internet forum were fundamental for the articulation of the national coordination team and municipal teams in PLP case throughout the preparation of the cleanup event. The members of the national coordination team were scattered through the country (actually, they only met in person after the cleanup event), and the municipal teams also kept in-person meetings to a strict minimum given that collaborators accumulated the volunteer work with their professional duties. Hence, these ICTs were especially valuable for them because they needed an effective way to discuss and report the progresses and difficulties they were experiencing in the preparation of the cleaning event.

In contrast, in person meetings were the norm for LDI case (particularly for Teeme Ära project), and hence the ICTs used and the pattern of communication were different. Whoever could not join these meetings had the possibility of connecting through Skype, and emails were also used, but mostly on one-to-one basis between team leaders and collaborators. The internationalization of the movement was accompanied by changes in the internal communication because a global team with collaborators from various countries was formed and they started to use an intranet and mailing lists.

With respect to the intranet, an LDI interviewee explained that it is mostly used by the regional coordinators [collaborators] for the management of contacts with countries... which is important for the continuity of work given the turnover[of volunteer collaborators]. Mailing lists are for communicating with the country teams, and are used for actively sharing information like: what are their plans for the future, what are they doing currently, upcoming cleanup dates in the network of 
countries - which is useful for doing communication together, and also inform on new partnerships created on anything related to that, as explained by an LDI interviewee.

The sub-categories facilitates brainstorming and hinders focus, are only relevant for PLP case. Brainstorming and the issue of lack of focus appear related only to the community website, during the preparation of the cleanup event. Users of the community website could contribute to all areas of the website and influence discussions, upon registering. A PLP organizer explained that there was an average of 100 or 150 daily comments, there was a lot of debate and discussion in that space... basically I could say my difficulties and together we could find solutions... and the ideas contributed would get corrected by the opinions of many people. And also noted that the only difficulty that Ning [community website] had was that it generated a lot of garbage as well. Unfortunately it was made in a way that didn't require the intervention of coordinators [to approve registration and comments], and so it generated a lot of discussion. Most of that was good because we could assimilate ideas from there, but there was also a lot of non-sense and that distracted us from the key issue, which was really what was important.

\section{Connectivity}

Organizing collective action always includes connecting people who have a shared interest in achieving a common goal (Flanagin et al., 2006; Marwell \& Oliver, 1993). Connectivity is important especially from the standpoint of eliciting support and contributions to collective action, and ICT-enabled connectivity is quite significant because it allows organizers to plug into networks where they can tap on social and human capital for the collective action events they organize. Our empirical data shows that the use of ICTs facilitated mobilization and proximity; but at the same time, the development of relationships of proximity and the mobilization of participants was, to some extent, hindered. We show illustrative quotations from the cases (LDI and PLP) in Table 3, with ICTs in bold indicating that they were used in both cases. As to table 2 of Annex 7, it crossreferences these ICTs and codes for the connectivity aspect.

\begin{tabular}{|c|c|c|}
\hline \multicolumn{3}{|c|}{ Category: Connectivity } \\
\hline Sub-category & Definition & Illustrative quotation \\
\hline $\begin{array}{l}\text { Facilitates mobilization } \\
\text { ICTs: blog, community } \\
\text { website, video sharing, } \\
\text { waste map }\end{array}$ & $\begin{array}{l}\text { Mobilization, defined as: } \\
\text { Ability to galvanize indi- } \\
\text { viduals or groups into ac- } \\
\text { tion in order to achieve a } \\
\text { collective goal }\end{array}$ & $\begin{array}{l}\text { I think it helped a lot, that video about the Estonian } \\
\text { cleanup... First because it all started with the people that } \\
\text { got impressed with that video in YouTube. Then, it was } \\
\text { easier to convince more people by revealing the video } \\
\text { and adding that the same could be done here, even with } \\
\text { more people and collecting more garbage (PLP case, or- } \\
\text { ganizer) }\end{array}$ \\
\hline $\begin{array}{l}\text { Hinders mobilization } \\
\text { ICTs: community website, } \\
\text { email, social networking } \\
\text { site, website }\end{array}$ & & $\begin{array}{l}\text { For me it was important to go to the meeting they orga- } \\
\text { nized because I wanted to understand better how things } \\
\text { were going to work on the day. I had read everything in } \\
\text { the website, but I think that only after hearing from them } \\
\text { [organizers] I got a better idea (PLP case, participant) }\end{array}$ \\
\hline $\begin{array}{l}\text { Facilitates proximity } \\
\text { ICTs: blog, community } \\
\text { website, email, skype, so- } \\
\text { cial networking site }\end{array}$ & $\begin{array}{l}\text { Proximity, defined as: } \\
\text { Becoming near in relation- } \\
\text { ship to individuals con- } \\
\text { nected to online spaces of } \\
\text { a collective action project }\end{array}$ & $\begin{array}{l}\text { Whenever someone enrolled in our Ning [community } \\
\text { website] group we sent them a personal email to, like, } \\
\text { create a tie. And then we wrote to them with news, ap- } \\
\text { proximately every week, like about partnerships we had } \\
\text { established and what was going on... this was to show } \\
\text { that there was work being done for the cleanup, and to } \\
\text { keep them close, so that they would not walk away (PLP } \\
\text { case, collaborator) }\end{array}$ \\
\hline $\begin{array}{l}\text { Hinders proximity } \\
\text { ICTs: email, internet fo- } \\
\text { rum, social networking }\end{array}$ & & $\begin{array}{l}\text { I think it's important to be close to volunteers... We } \\
\text { email them the newsletter [of AMO Portugal] and post } \\
\text { our news in Facebook... Yeah, I think we need other so- }\end{array}$ \\
\hline
\end{tabular}




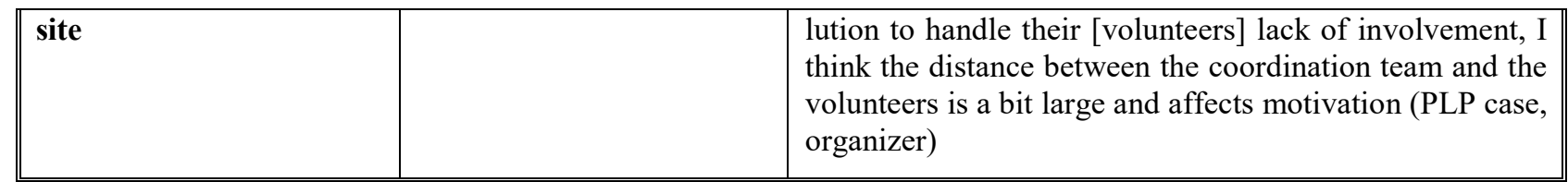

Table 3: How the use of ICTs affects connectivity, within collective action organizing (ICTs in bold indicates use in both cases)

In PLP and LDI, organizers used ICTs to grow connections with participants and supporters (sponsors). LDI used social media to a limited extent before the cleaning event because in 2008 and 2009 popular social media platforms, such as Facebook and Twitter, were not established in Estonia yet. Nonetheless, the sharing of the 5-minute video about the Estonian cleaning event that was produced in 2009 and published in YouTube, had a large impact in terms of catalyzing collective action in other countries, as this LDI interviewee explained: what we have mostly is that somebody finds about us and is inspired by the 5-minute video. Then, getting a country team onboard is easier.

The ICTs associated with with facilitated mobilization are blog, community website, and waste map in the case PLP, and also video sharing in both cases. Only some of these ICTs have network effects (video sharing and community website), and a common denominator is the ability to provide information about the problem to be solved, usually curated information and in different formats (e.g. video sharing, blogs, waste map). We were expecting to see the mobilization of participants especially linked with memes and viral messages shared in social networking sites or sent via email. However, the data shows that participants need more than that, they need to have a clear idea of how the collective action is going to work, what are they contributing to, and they need to trust on who is behind it. For this, other ICTs are more helpful, such as video sharing and blog (the how to), the waste map (the what), and the community website (to complement personal contact with the organizers and with friends and acquaintances involved).

For both cases, email, social networking site, and website did not have a positive effect on mobilization. An LDI interviewee explained that a bad side is that messages now have to be much stronger because there is an overflow of messages. If you are in Facebook, you see a lot of messages everyday so it has to really stand out. And also, you know, if you meet somebody in person and if you hear something from a person it has much larger effect than when you get an email or some kind of virtual message. So it's easier to make connections now, through social media and Internet, but they are weaker... and so you have to work differently because you can't reach the goals set if you just get people engaged in the Internet. They actually have to come out and do something in the real physical world and making that shift from virtual to real world is a challenge.

In PLP case, participants enrolled for the first country-scale cleaning event through the community website, where they could have a global view of participation. Indeed, a PLP interviewee noted that: with Ning [community website] the volunteer feels that he is part of something big that is happening, right? when we see the enrollment numbers growing, and every day more members, every day more groups... we feel that we are part of something that is worthy and that other people want to be part too. However, after the deactivation of the community website, enrolment of participants through the website of AMO Portugal and social networking sites did not enact the same kind of visibility, and perhaps that explains the negative effects on mobilization.

For motivated participants, it is possible to enlist as volunteer of AMO Portugal through a form in the website. AMO Portugal also has its own Facebook page and the municipalities that still have an active team have groups and pages in Facebook too, where they announce the events they organize. Because these various pages are not related or connected, except for the "like" they exchange, it is difficult for participants to get a sense of how big the network of AMO Portugal actually is. Whereas the community website was focused, Facebook is a generalist social networking site that brings in the additional challenge of thousands of posts trying to attract "likes". 
On the one hand, the enrolment of a participant through the website of AMO Portugal creates a connection between that participant and organizers, but this connection is not visible to others. On the other hand, enrolment through Facebook makes individual connections visible to others but, since pages and groups related to AMO Portugal are not collated within Facebook, participants cannot see the "whole picture" of enrolment. Inasmuch as there is no connection between enrolment in the website and enrolment in Facebook (following pages, joining groups, and signing up for events), the use of these two ICTs in combination actually fragments enrolment numbers and mobilization.

Proximity, in relation to the use of ICTs, refers to cultivating relationships with other people through ICT-mediated interaction in order to build a sense of community and belongingness. Establishing these close relationships is important for PLP and LDI organizers because the events they organize depend on having a huge number of volunteers showing up for work on certain dates. Our cases data shows that establishing proximity requires more direct and personal interaction, for example via skype, community website, and followship of blogs. When the possibilities for real, live interaction, are very limited or do not exist at all, it is nevertheless important to cultivate proximity - even through social media. As an LDI interviewee said: these channels [social media] don't substitute getting together but still... you know, they keep people closer. Without the Internet I really don't know how it could work. Nevertheless, this kind of proximity is weak and cannot be sustained in the long term. Both email and social networking site have negative and positive effects on proximity, and this also happens for internet forum in PLP case. An LDI interviewee acknowledged that what I have again and again witnessed is that you can have emails and skype as much as you want, and you can make them very effective also, but nothing beats the actual opportunity to meet people face to face. It's the most effective thing to have, to really create some long-lasting relationships and trust also.

\section{Coordination}

Coordination via ICTs is especially useful for the collective action of groups that face the challenge of geographical distance (Coopman, 2011; Klein, 1999). The use of ICTs allows for asynchronous communication and therefore can bridge temporal constraints that may obstacle coordination (Hampton, 2003). The data from our cases gives additional pointers on how the use of ICTs affects coordination, in relation to organizing collective action. The use of ICTs facilitates different aspects of coordination, namely: segmentation (within group coordination); persistence of information (coordination over time); and standardization of contributions (coordination of tasks). However, ICTs also hindered unification (between group coordination), and direction (coordination of tasks). We show illustrative quotations from the cases (LDI and PLP) in Table 4, with ICTs in bold indicating that they were used in both cases. As to table 3 of Annex 7, it cross-references these ICTs and codes for the coordination aspect.

\begin{tabular}{|l|l|l|}
\hline \multicolumn{3}{|c|}{ Category: Coordination } \\
\hline Sub-category & Definition & Illustrative quotation \\
\hline $\begin{array}{l}\text { Facilitates segmentation } \\
\begin{array}{l}\text { ICTs: community website, } \\
\text { internet forum, mailing list }\end{array}\end{array}$ & $\begin{array}{l}\text { Ability to exchange infor- } \\
\text { mation within subgroups } \\
\text { of similar characteristics, } \\
\text { needs, and objectives. }\end{array}$ & $\begin{array}{l}\text { They re-organized the mailing lists, created some more, } \\
\text { put people in different sectors, and from that point people } \\
\text { started to share information in the right mailing lists, } \\
\text { which helped a lot because before when information was } \\
\text { sent to all the lists, to everybody... It didn't really work, } \\
\text { and then people started, you know, avoiding reading all } \\
\text { the emails (LDI case, organizer) }\end{array}$ \\
\hline $\begin{array}{l}\text { Facilitates persistence of } \\
\text { information }\end{array}$ & $\begin{array}{l}\text { Ability to use accumulated } \\
\text { information about past in- } \\
\text { iCTs: community website, } \\
\text { intranet }\end{array}$ & $\begin{array}{l}\text { The advantage of having all the meetings minutes on the } \\
\text { sent and future actions } \\
\text { intranet website, hum I think it gives really everyone the } \\
\text { possibility to have an overview. I mean if you are a team } \\
\text { member you can see what has happened before. It's... for } \\
\text { the continuity it's really important. (LDI case, collabora- }\end{array}$ \\
\hline
\end{tabular}




\begin{tabular}{|l|l|l|}
\hline $\begin{array}{l}\text { Facilitates standardization } \\
\text { of contributions }\end{array}$ & $\begin{array}{l}\text { Establish common under- } \\
\text { standings and procedures } \\
\text { through structured infor- } \\
\text { mation, distributed at col- } \\
\text { lCTs: community website, } \\
\text { logistics system, waste got the paper, where it was written where they } \\
\text { map, website } \\
\text { lectind that sheet was a logistic system that divided all the } \\
\text { trash points among the people, and that also made people } \\
\text { think that this is so well organized and well done (LDI } \\
\text { case, organizer) }\end{array}$ \\
\hline \hline $\begin{array}{l}\text { Hinders unification } \\
\begin{array}{l}\text { ICTs: cleanup form, intra- } \\
\text { net, mailing list, social } \\
\text { networking site, website }\end{array}\end{array}$ & $\begin{array}{l}\text { Difficulty in perceiving } \\
\text { different groups as being } \\
\text { tive in a common objec- }\end{array}$ & $\begin{array}{l}\text { In Facebook they could see information only about our } \\
\text { group, if they wanted to see the national event they had } \\
\text { to go to the website... if we had a platform dedicated on- } \\
\text { ly to the event it would be easier to see everything [the } \\
\text { overall picture] (PLP case, organizer) }\end{array}$ \\
\hline $\begin{array}{l}\text { Hinders direction } \\
\text { ICTs: community website }\end{array}$ & $\begin{array}{l}\text { Difficulty in orienting the } \\
\text { course of actions that are } \\
\text { necessary to achieve a } \\
\text { common objective }\end{array}$ & $\begin{array}{l}\text { It took a long time for Ning [community website] to } \\
\text { work as we wanted... at some point, if you go in there it } \\
\text { looked more like a field battle than people doing some- } \\
\text { thing like hum... working for some kind of common } \\
\text { good (PLP case, organizer) }\end{array}$ \\
\hline
\end{tabular}

Table 4: How use of ICTs affects coordination, within collective action organizing (ICTs in bold indicates use in both cases)

For the global LDI movement, the core team and the country teams felt the need for group level coordination through dedicated information flows, but the organizing team of Teeme Ära did not feel this need earlier because the national cleaning event had, to a large extent, been centrally organized. The ICTs associated with facilitating this segmentation of information flows are the community website, and internet forum in PLP case, and mailing list in LDI case. In PLP case, the preparations of the national cleaning event involved the coordination of teams working at municipal, district, and national levels. Each team had its own group within the community website, and this segmentation was instrumental for structuring the groups' collective action at different levels. A PLP interviewee explained that, personally, I think that from the moment there was a hierarchy of the process [national, district, and municipal teams] it was easier for people to associate to different groups in Ning [community website], depending on what they thought they could collaborate on.

In both cases, the use of ICTs also facilitated the persistence of information over time. The use of repository-like ICTs contributed to this: the community website and the website, for PLP case, and intranet, for LDI case. The possibility of seeing and understanding what has been done in the past is important for coordination because organizers had to work with an unstable base of collaborators. In this respect, a PLP interviewee conveyed that, I joined quite late, in my municipality they had been working on it for quite a long time... But based on the records in Ning [community website], I could figure out what they had already done and what they needed now, so I could look for the way I could be of help.

The waste map, the logistics system, and the website facilitated coordination at task level, that is, facilitated the standardization of individual-level contributions to certain tasks (registration, mapping of dumpsites, assignment of cleaning areas). In PLP case, the community website facilitated discussion of ideas to overcome the difficulties that arose in the preparatory phase of the cleanup event, which were often conducive to solutions that involved division of labor and standardization of tasks. The breakdown of work into normalized tasks was done not only for predominantly online tasks (e.g. mapping dumpsites), but also for offline tasks, such as prospecting for partners. As a PLP interviewee said, Most of them [participants] only appeared on the 20th of March, but a large number also pitched in to contact companies they knew or they sent us the photos and location of dumpsites they had found in the forest.

For participants, this normalization of tasks provides the comfort that things are well organized and that their contribution is meaningful. It is important that participants understand not only how they should perform a task, but also why that task is necessary and what does it contribute to. A partici- 
pant in PLP conveyed that, I decided to participate after seeing the website because things were very well organized. I like to participate but I don't like to waste time, and when I see that things are not well planned, hum I start to think that the result will not be the one we want... of course the environmental part moves me, but it was more because everything was well structured, and we knew what we were going to do and how we were going to do it...

The use of ICTs may also create difficulties that obstruct between-group coordination. For example, fragmentation of information in multiple sites, or lack of linkages between information create confusion and hinder unification of groups' action. In PLP case, difficulties in between-group coordination arose for the collective actions organized after the deactivation of the community website, which was substituted by a combination of a registration form in the website of AMO Portugal and Facebook groups or pages for active municipal groups. A PLP collaborator reported that officially [in the website] there was only the municipal group I had created, but then I found out, because someone told me, that an NGO and a parish had their own groups as well, in Facebook. And so we were working separately because of lack of coordination because there wasn't a centralizing platform. An LDI interviewee also expressed that what we saw as a problem was that we created a lot of channels for sharing information but people [country teams] were not really reaching out to them and what we established at the workshop was that people don't realize how big the network is and how they can benefit from it.

In PLP case, the lack of restricted areas in the community website led to problems of unclear direction, which organizers had to address early on. Hence, the community website had positive (standardization of contributions) and negative effects (hindering direction) on task-level coordination. This finding is consistent with what Leong et al. (2015) report as collaborative control achieved via social media because in their case there was control over what information was disseminated, and the organizers made sure that the right information was posted. However, that was not the case for PLP and indeed the activity of organizers was susceptible to disruptive interventions, as this PLP interviewee put it: I do not recommend others to use Ning [the community website] the way we did it. The problem was that registration and comments were automatic, and anyone could visit the page of any team and immediately start to criticize what the team was doing just for the sake of causing disorder. And added, there were people trying to become key protagonists and with ambitions to steer the movement to certain directions... and other with totally inappropriate topics... so we came to a point where we had to delete topics and comments, and actually had 2 people with the only job of daily checking the community website for inappropriate content.

\section{Legitimacy}

Legitimacy seems to be especially important in the early stages of collective action organizing. For society to take action upon social problems, a process of collective definition of legitimate problems takes place. Certain affordances for practice of social media can establish the legitimacy of organizations in the charity sector, namely enforcing transparency, enhancing accountability, and enacting public scrutiny (Zheng \& Yu, 2016). But how do groups like LDI and PLP establish the legitimacy of their collective actions? Our cases show that legitimacy is associated with facilitated credibility and visibility, which are associated with use of ICTs. We show illustrative quotations from the cases (LDI and PLP) in Table 5, with ICTs in bold indicating that they were used in both cases. As to table 4 of Annex 7, it cross-references these ICTs and codes for the Legitimacy aspect.

\begin{tabular}{|l|l|l|}
\hline \multicolumn{2}{|c|}{ Category: Legitimacy } \\
\hline Sub-category & Definition & Illustrative quotation \\
\hline $\begin{array}{l}\text { Facilitates credibility } \\
\text { ICTs: community website, } \\
\text { email, logistics system, } \\
\text { waste map, website }\end{array}$ & $\begin{array}{l}\text { Being perceived as trust- } \\
\text { worthy and convincing }\end{array}$ & $\begin{array}{l}\text { We only use the website and our personal email. Face- } \\
\text { book we don't use it because it's associated with banali- } \\
\text { ties... in reality there has to be an official website that } \\
\text { lends credibility to what we are doing, so that people see } \\
\text { they are participating in something that is trustworthy }\end{array}$ \\
\hline
\end{tabular}




\begin{tabular}{|l|l|l|}
\hline $\begin{array}{l}\text { Facilitates visibility } \\
\text { ICTs: waste map }\end{array}$ & $\begin{array}{l}\text { (PLP case, organizer) } \\
\text { tract attention or becoming } \\
\text { prominent }\end{array}$ & $\begin{array}{l}\text { By virtually mapping your trash points inside the coun- } \\
\text { try, you are really able to show virtually what is trash } \\
\text { problem in the country... sometimes the tool can be } \\
\text { problematic to use, for example in country X they want- } \\
\text { ed to make the civic action but didn't want to use it be- } \\
\text { cause it would make the problem public and cast a nega- } \\
\text { tive light [on authorities]... (LDI case, organizer) }\end{array}$ \\
\hline
\end{tabular}

Table 5: How use of ICTs affects legitimacy, within collective action organizing (ICTs in bold indicates use in both cases)

With regard to credibility, the provision of a website with structured, authoritative, and constantly updated information about the collective action events organized and in preparation, is an important means for showing organizing capacity and for organizing teams to earn trust from prospecting participants and sponsors. In this respect, an organizer from PLP case noted: The guidelines [about how to organize a collective action event] also exist to show our potential sponsors that we are doing something that is thoroughly thought and organized, and to make them aware of the actual impact we want to have. Otherwise, they will not take us seriously and without their support we can't $d o$ it. The logistics system and the waste map also showed organizing capacity and build credibility. As an LDI interviewee said, it makes people think that this is so well organized and well done, and that's a comfort for them because they believe it will work.

Mapping the waste makes the dumpsites visible and creates the "whole picture" of the problem. Before mapping, the knowledge about the extent of dumping was local, that is, it was only the people that lived in the affected areas who experienced it. After the mapping exercise the extent of dumping was for the first time known at the country scale, and could then be framed as a public environmental problem, which was subsequently discussed in various media outlets.

To the extent that the dumping problem is made visible and known to the wider public, there is more questioning about why the problem exists and more consensus about the need to support solutions to the problem. As an LDI interviewee put it: it is useful, if nothing else, because you can show it to the media and to people - ok, do you see all this crap that is in there? we need to clean it up. So it's a tool to show how big and important the problem is. The shared awareness of the waste problem prompts stakeholders (municipalities and local authorities) to take action because of reputation concerns. This results in the mobilization of local authorities to support the organizing of the cleaning event, and consequently reinforces the legitimacy of civic movement.

\section{Organizing costs}

Supporting the organizing of collective action with ICTs reduces the costs of traditional organizing practices, such as recruitment and fundraising (Lev-On \& Hardin, 2008). Costs are low not only because ICT-based communication is inexpensive but also because resource mobilization strategies based on the connectivity facilitated by ICTs are sensitive to reach and selectivity. Indeed, through ICT-based connectivity it is nowadays possible to access a wide audience (reach) and engage the most interested contributors (selectivity). Earl and Kimport (2011, p. 153) studied tactics of online activism, such as e-petitions, and argue that organizing online is "inexpensive enough that it can begin to follow a power-law dynamics in some situations". In other words, costs are so low for online collective action that in reality few people may bear all or the majority of costs of organizing. This means that a very small team, or in the limit one individual only, may be able to organize collective actions with accelerative production functions (collective actions that require scale).

According to the empirical data examined, the connection between use of ICTs and costs of organizing collective action exists beyond inexpensive means of mobilization of resources. The use of ICTs links to organizing costs via the concepts of facilitated efficiency and facilitated scalability. We show illustrative quotations from the cases (LDI and PLP) in Table 6, with ICTs in bold indi- 
cating that they were used in both cases. As to table 5 of Annex 7, it cross-references these ICTs and codes for the organizing costs aspect.

\begin{tabular}{|l|l|l|}
\hline \multicolumn{2}{|c|}{ Category: Organizing costs } \\
\hline Sub-category & Definition & Illustrative quotation \\
\hline $\begin{array}{l}\text { Facilitates efficiency } \\
\begin{array}{l}\text { ICTs: community website, } \\
\text { documents sharing, email, } \\
\text { mailing list, registration } \\
\text { form, social networking } \\
\text { site, waste map }\end{array}\end{array}$ & $\begin{array}{l}\text { imum expenditure of re- } \\
\text { sources }\end{array}$ & $\begin{array}{l}\text { Emails, that's how we contacted partners. Emails and of } \\
\text { course phones. But phones after emails. More use of } \\
\text { same message, but rephrased depending on the partner, } \\
\text { and that's very efficient - to get the largest possible num- } \\
\text { ber of contacts in a short time. (LDI interviewee, organ- } \\
\text { izer) }\end{array}$ \\
\hline $\begin{array}{l}\text { Facilitates scalability } \\
\text { ICTs: community website, } \\
\text { internet marketing, social } \\
\text { networking site }\end{array}$ & $\begin{array}{l}\text { Ability to expand the range } \\
\text { of influence of some action }\end{array}$ & $\begin{array}{l}\text { I think the project wouldn't have been the same if they } \\
\text { didn't create this [community website] from the start. } \\
\text { Most likely it would have resulted in something with a } \\
\text { minor scale... Locally, it's not that important but it mat- } \\
\text { ters if you're doing something at country scale (PLP } \\
\text { case, organizer) }\end{array}$ \\
\hline
\end{tabular}

Table 6: How use of ICTs affects organizing costs, within collective action organizing (ICTs in bold indicates use in both cases)

In both cases, interviewees reported that the use of ICTs allowed them to produce certain outcomes quickly and easily. The recurrent example is email, as many interviewees have said: if there was no email, communication would be slow and expensive. For LDI global movement is also about reducing work duplication, as an interviewee said: we have a basic waste map in place and people all over the world can use it, so countries don't need to waste resources building one for themselves.

Scalability is linked with exploitation of network effects in PLP's community website and social media platforms, and via internet marketing in LDI case. However, in both cases this was not enough to create a country-scale collective action event. These means were coupled with a communication campaign that involved traditional media and regular networking, as a PLP interviewee explained: for the scale we had, I don't think it was Ning [community website] that got us there... I also don't think that it was advertising in television and radio that made the difference. I'm sure people got curious with all that and visited the site... but there was a lot of work behind. We had to show up, to go to the bars and cafes and distribute flyers and talk to people.

The use of ICTs contributed to scalability and increased efficiency or organizers' work, which resulted in lower organizing costs. Yet, the total organizing costs remain high for collective actions that involve more than online activities. In PLP and LDI cases, organizers performed more than relatively simple and inexpensive online actions (e.g. connecting with participants in the community website, communicating via the mailing list, posting and commenting on social networking sites). They also performed costlier offline actions, such as, engaging sponsors and patrons, engaging participants offline, and more complex combined online and offline actions, such as contributing volunteered geographic information.

\subsection{Cross-case Analysis}

The results of cross-case analysis are summarized in Table 7. In addition, a summary of facilitator and hinderer role of ICTs, for both cases, is provided in table 6 of Annex 7. Table 7, in the next page, shows the categories and sub-categories most relevant for each case. The table is useful to show how the effect of ICT use varies for different configurations of collective action organizing, as it covers the evolution that PLP and LDI had over time. Although Teeme Ära and Let's Cleanup Portugal are two cases of a similar kind of collective action event, they are not alike in terms of organizing structure - PLP had a decentralized structure at municipality level, and Teeme Ära was 
centrally organized by a core team. It could be that different organizational arrangements may explain some cross-case case variability.

Perhaps due to the more centralized organizational structure of Teeme Ära, the effect of ICTs in the organizing of their collective action event is more limited. The fact that the privileged form of communication among organizers was personal contact and that external communication rested mostly on traditional media also accounts for the relative insignificance of the dimensions communication, connectivity, and coordination.

There are more similarities, cross-case wise, between the global movement LDI World and Let's Cleanup Portugal. Again, this may be explained by the homologous kind of organization structure underpinning these collective action groups, which was highly decentralized, and hence required more ICT-based communication, coordination, and connectivity. Unsurprisingly, there is less within case variability in PLP case. Since Teeme Ära evolved into a transnational movement, the objectives and the kind of collective action that this global movement engages in require different uses of ICTs, when compared with the previous country-scale collective action events organized by Teeme Ära.

Overall, in our results we identify aspects of collective action organizing (organizing functions and requirements) that are affected by the use of ICT ensembles, and show how the use of these ICTs affect, both positively and negatively, these aspects. So, to answer our research question we can say that the use of ICTs affects communication, connectivity, coordination, legitimacy, and organizing costs, and, within each of these aspects of organizing, the use of ICTs can expedite certain aspects and frustrate others. These findings suggest that the organizing of collective action can indeed be facilitated by the use of ICTs, but the actual outcome of organizing work (participation) remains unpredictable.

\begin{tabular}{|c|c|c|c|c|}
\hline \multirow[b]{2}{*}{ Categories and sub-categories } & \multicolumn{2}{|c|}{ Case LDI } & \multicolumn{2}{|c|}{ Case PLP } \\
\hline & Teeme Ära & LDI World & Cleanup Portugal & AMO Portugal \\
\hline \multicolumn{5}{|l|}{ Communication } \\
\hline Facilitates dissemination of information & $\mathrm{X}$ & $\mathrm{X}$ & $\mathrm{X}$ & $\mathrm{X}$ \\
\hline Facilitates brainstorming & & & $\mathrm{X}$ & $\mathrm{X}$ \\
\hline Facilitates reporting & & $\mathrm{X}$ & $\mathrm{X}$ & $\mathrm{X}$ \\
\hline Hinders focus & & & $\mathrm{X}$ & \\
\hline \multicolumn{5}{|l|}{ Connectivity } \\
\hline Facilitates mobilization & & $\mathrm{X}$ & $\mathrm{X}$ & \\
\hline Hinders mobilization & $\mathrm{X}$ & $\mathrm{X}$ & $\mathrm{X}$ & $\mathrm{X}$ \\
\hline Facilitates proximity & & $\mathrm{X}$ & $\mathrm{X}$ & \\
\hline Hinders proximity & & $\mathrm{X}$ & & $\mathrm{X}$ \\
\hline \multicolumn{5}{|l|}{ Coordination } \\
\hline Facilitates segmentation & & $\mathrm{X}$ & $\mathrm{X}$ & $\mathrm{X}$ \\
\hline Facilitates persistence of information & & $\mathrm{X}$ & $\mathrm{X}$ & $\mathrm{X}$ \\
\hline Facilitates standardization of contributions & $\mathrm{X}$ & & $\mathrm{X}$ & $\mathrm{X}$ \\
\hline Hinders unification & & $\mathrm{X}$ & & $\mathrm{X}$ \\
\hline Hinders direction & & & $X$ & \\
\hline Legitimacy & & & & \\
\hline
\end{tabular}




\begin{tabular}{|l|cc|cc|}
\hline \multirow{2}{*}{ Categories and sub-categories } & \multicolumn{2}{|c|}{ Case LDI } & \multicolumn{2}{c|}{ Case PLP } \\
& Teeme Ära & LDI World & Cleanup Portugal & AMO Portugal \\
\hline Facilitates credibility & $\mathrm{X}$ & $\mathrm{X}$ & $\mathrm{X}$ & $\mathrm{X}$ \\
Facilitates visibility & $\mathrm{X}$ & $\mathrm{X}$ & $\mathrm{X}$ & \\
\hline Organizing costs & & & & \\
Facilitates efficiency & $\mathrm{X}$ & $\mathrm{X}$ & $\mathrm{X}$ & $\mathrm{X}$ \\
Facilitates scalability & $\mathrm{X}$ & $\mathrm{X}$ & $\mathrm{X}$ & $\mathrm{X}$ \\
\hline
\end{tabular}

Table 7: Comparison of categories and sub-categories

In other words: if organizers build it, participants may or may not come. As an LDI interviewee put it: we realized that: ok, we can make so detailed instructions and we can optimize with IT and whatever, but in the end people will do what they think is best (...) So we had to let go, just let go! Yes, especially a few days before the cleanup, at that point you can't do anything anymore. It's a bit frightening but on the other hand it was pretty nice because suddenly practically all email died, and everyone was just waiting. And a PLP interviewee conveyed an identical perspective: In this municipality volunteers were basically waiting to see what was going to come out of what we [organizers] were doing... We didn't have much feedback [in community website], and this made it difficult for us because we couldn't know if we were going to have 250 volunteers or 1000 volunteers [in the cleaning event]. If we just relied on Internet, we could have had problems... suppose that suddenly lots of people appear? or no one? To overcome that, we contacted and talked to lots of people directly, in order to get a firm compromise that they were coming. And that's a different kind of compromise that we get from people saying in a site they will come.

\section{Discussion}

This article investigates the effects of use of ICT ensembles on the organizing of consensual collective action. Previous literature dealing with different forms of collective action has identified generic effects of ICT use on organizing collective action, such as changing costs of communication (Lin \& Dutton, 2003a; Nielsen, 2009) and costs of organizing (Earl \& Kimport, 2011); removing constraints of time and space (Earl \& Kimport, 2011; Hampton, 2003; Klein, 1999); and re-defining access to power structures (Hara \& Youngmin, 2007; Lin \& Dutton, 2003a). However, why and how exactly these effects happen is still relatively unexplored in the collective action and digital technologies literature.

Our study goes beyond the identification of generic effects and demonstrates the impact of the integrated use of ICTs on organizing collective action, showing exactly what organizing functions and requirements are affected. In addition, it explains the type of effect - facilitating or hindering. The results, as depicted in Figure 1, show that ICT ensembles both facilitate (plus signal) and hinder (minus signal) organizing functions and requirements of collective action. These positive and negative effects happen in most aspects studied. The exceptions are the organizing costs and legitimacy, where the ICT ensembles used seem to have only facilitating effects. 


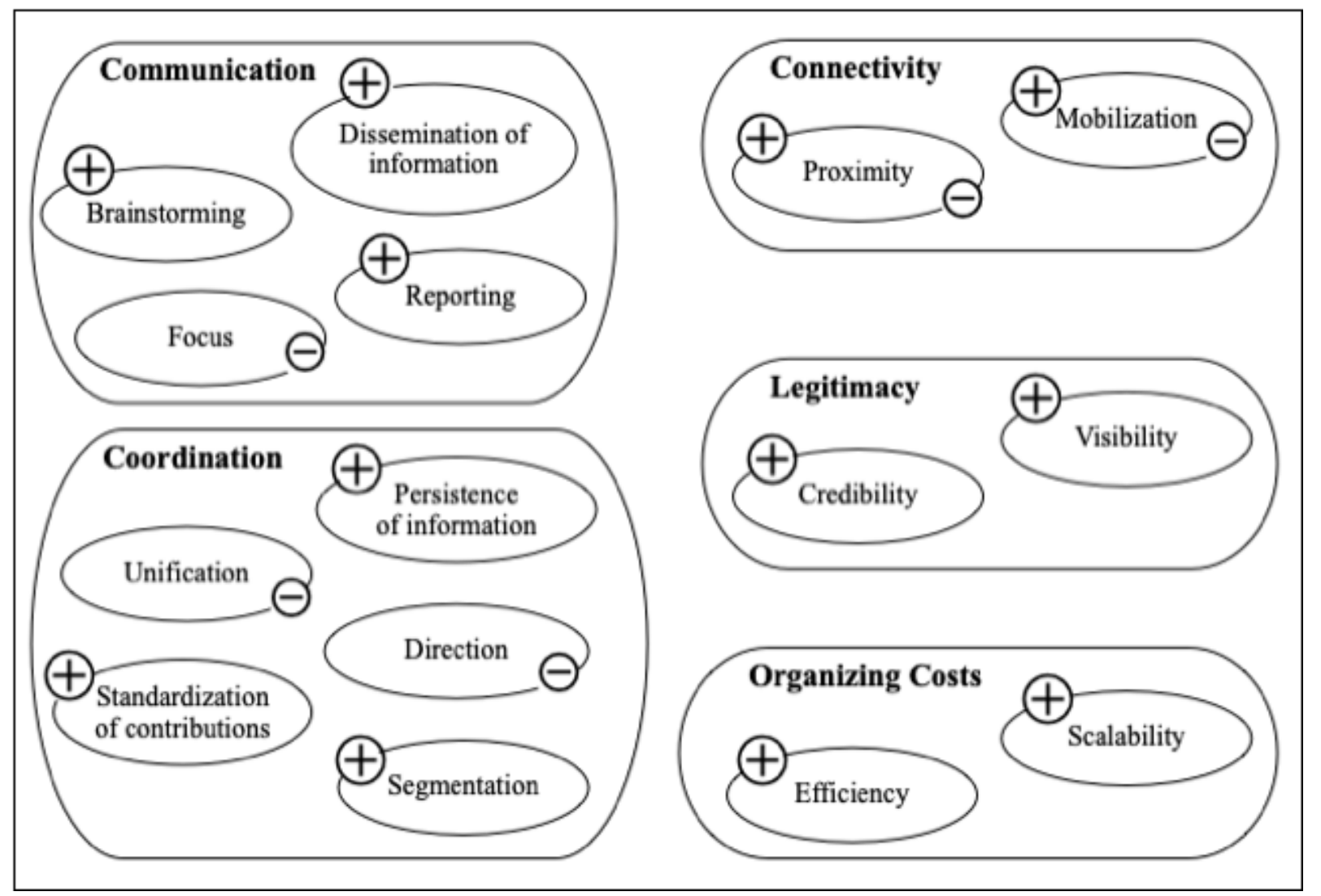

Figure 1: Effects of ICTs on organizing functions and requirements of collective action

These findings show that the integrated use of ICTs is substantially empowering for organizers, with clear benefits in terms of legitimacy and organizing costs, and also positive effects on coordination, communication, and connectivity. At the same time, their use may also constrain the connecting with participants (mobilization and proximity) and hinder aspects related to coordination of work (direction and unification) and effective communication (focus). Considering the integrated use of ICTs, which was the focus of our analysis, it is unfeasible to sort out which specific ICTs could be discarded in order to avoid or reduce the constraining effects. We know, however, that the community website was the single ICT that hindered focus in communication, and caused problems of direction on task-level coordination. Yet, that same community website had positive effects on all the other aspects related to coordination and to communication, including sole responsibility for facilitating brainstorming.

With respect to the constraining effects on communication, what becomes salient in our analysis is that it matters how participatory ICTs, such as the community website, are configured. Probably, a better focus of communication could be attained with a different configuration of the community website. The issue was that registration and comments were not moderated and while this empowered participants to contribute in positive ways (e.g. brainstorming, reporting, and sharing information), it also produced a lot of noise and distraction from the core objective. This configuration also facilitated that others than organizers were able to influence the direction of work, with negative effects on task-level coordination.

For coordination, besides this effect on direction, there were constraints in terms of unification of the groups and the information scattered in different ICTs. To us, this suggests that the ICTs in the ICT ensemble were actually difficult to integrate in practice. Possibly this would require more technical skills, from the organizers side, in terms of developing software and applications. The possession of communication and computing technical skills is actually deemed to have played a major 
role in organizing other collective actions, namely in the case of Los Indignados movement in Spain (Micó \& Casero-Ripollés, 2014). Moreover, it is likely that the combination of ICTs used did not support end-to-end collective action organizing and contributed to gaps in the organizing process (Shaw et al., 2014), with consequences in terms of fragmentation.

The results also show that the use of ICTs had positive effects on legitimacy and organizing costs. Reduction of costs are known from previous studies (e.g. Earl \& Kimport, (2011; Lin \& Dutton, (2003b); Nielsen, (2009)). Reduced costs are typically linked to inexpensive means of communication provided by ICTs. It seems that the low costs of communication have already been internalized because our study shows that costs are lower because the ICTs used improved efficiency in the tasks performed by the organizers and also allowed for scale effects with minimum expenditure of resources. With respect to legitimacy, the collective actions examined in this research achieved high levels of legitimation that was reflected in their consensual nature. ICTs had positive effects on visibility and credibility. The visibility of the littering problem enabled cognitive legitimacy, whereas credibility contributed to sociopolitical legitimacy (T. Hargrave \& Van De Ven, 2006).

The impacts of ICTs on connectivity (proximity and mobilization) are inconclusive. Connecting to people with potential interest to contribute to collective action has become easier with ICTs, especially through social media. Although the engagement of participants depends on many factors, there are certainly ways to encourage participation that involve the use of ICTs in particular ways. For example, the fact that some ICTs make participation visible is consequent in terms of mobilization (Hampton, 2003). Threshold models of collective behavior (Granovetter, 1978) suggest that individuals' propensity to engage in a certain behavior depends on the proportion of people already engaged in that behavior. This is especially relevant in the kind of collective action that LDI and PLP organize because the events they organize have an accelerating production function. This means, according to the critical mass theory of collective action, that a threshold of participants is required to create the conditions for the involvement of many others (Marwell \& Oliver, 1993), and therefore we expect that ICTs' network effects have an important role in mobilization in both LDI and PLP cases.

When the ICTs used do not offer opportunities for participants to engage with collective action in more personalized terms (e.g. widgets that facilitate sharing, possibility of interaction with organizers and other participants), network effects are difficult to exploit (Bennett \& Segerberg, 2013; Wright, 2015). For example, websites are good broadcasting platforms that offer ownership and control over content (good for organizers) but they need to be made more participatory in order to seize network effects. For network effects to become significant, a critical mass of connections is required (Markus, 1987). In the absence of this critical mass, it is unlikely that a collective action will grow the necessary connections to become viable (Marwell and Oliver, 1993).

Engaging a critical mass of organizers is difficult per se, yet it is becoming even harder within incorporated social media. Incorporated social media platforms like Facebook, YouTube, and Twitter are tuned to users' desire to make connections and share user-generated content. Although these platforms articulate a feeling of connectedness and collectivity, connectivity within these platforms is engineered by opaque algorithms that are staked on the values of popularity, hierarchical ranking, and personalized recommendations (Van Dijck, 2013). Consequently, the dynamic nature of these algorithms meddle in how connectivity is in fact created among users because visibility in these platforms is "subject to various ranking, sorting and classification algorithms" (Bucher, 2012, p. 1176).

When collective action is supported by social media platforms or other commercial web-based platforms, the agency of organizers and participants is amplified and co-structured by these ICTs. Collective action is structured according to rules that are coded in these platforms, which incentivize 
certain behaviors and discourage others (Van Dijck, 2013; Dolata \& Schrape, 2015). Under these conditions, it seems that tapping on the connectivity afforded by incorporated social media platforms to organize collective action is increasingly difficult. These commercial platforms are fundamentally looking for ways to monetize the data and metadata that users voluntarily cede in exchange for connectivity, and therefore their technological architecture and business model are not oriented towards facilitating consensual or conflictual collective action (protest movements). They are empowering and, at the same time, exploiting users because "sociality is enjoyed and exercised through precisely the commercial platforms that also exploit online social activities for monetary gains." (Van Dijck, 2013, p.18).

The success of collective action supported by ICTs should not clash with the economic logic of corporate social media. For instance, in PLP case, when the community website was terminated, the content was siloed in the Ning platform and could not be transferred to another platform. As a result, there was a major breakup with the community that had been created through that platform with consequences for the future of the movement Let's Cleanup Portugal and the association AMO Portugal. These rifts are not irreconcilable because sometimes communities are able to reassemble. However, a valuable lesson from this case is that ownership of content and control over communication platforms is important for the longevity and resilience of civic movements supported by ICTs.

Overall, the success of collective actions like those that PLP and LDI organized (success meaning the provision of the collective good), is profoundly linked to the capacities and intentions of the individuals and organizations behind it. Mass collective action events like those organized by PLP and LDI require a lot of preparatory work. There has to be a critical mass of organizers who work relentlessly in the practical aspects of organizing a large-scale event, and mobilize people and organizations from all quadrants to contribute and participate. Organizers, in PLP and LDI cases alike, were primarily volunteers devoted to a cause, bounded by an organizational structure (formal or informal), who were collaborating with others in similar circumstances, and were using ICT ensembles to support the organizing process, while doing a significant amount of offline work.

As such, in both of our case studies, we argue that the use of ICTs is instrumental. In general, the use of ICTs in these collective actions supports the activities of organizers and their interaction with participants. However, without the contribution of resourceful sponsors and motivated participants, collective action does not take off. Therefore, we argue that although the use of ICTs allows organizers to operate purposefully in order to organize collective action, the extent to which they succeed in the actual concretization of collective action depends on their capacities and intents. This suggests that human factors are, to a great extent, implicated in the success of collective action supported by ICTs. The effect of technology in collective action situations is, as Toyama (2010, p. 29) puts it, "to amplify human forces. Like a lever, technology amplifies people's capacities in the direction of their intentions". This is in line with human agency positions about the consequences of information technology, which suggest that ICTs are "implicated in social change at the discretion of human agents" (Boudreau \& Robey, 2005, p. 4).

\section{Conclusion}

We found that, on the whole, the use of ICTs empower and constrain the agency of organizers and participants in these movements, and we argued that the success of collective action organizing is predicated in human forces and in social processes. This argument was based on the critical observation of how these consensus movements were structured and how they operated.

\subsection{Theoretical and Practical Contributions}

This study offers three theoretical contributions. First, it contributes to deepen the understanding of the role of ICTs in the organizing of collective action. Our research elaborates on how the ICT en- 
sembles used in successful collective actions had positive and negative effects on the functions and requirements of organizing, namely effects on communication, coordination, connectivity, organizing costs, and legitimacy. For example, while we knew from before that ICTs had impacts on costs of organizing (Earl \& Kimport, 2011), now we know exactly what ICTs affect that contributes to lower the costs. Second, this study contributes to expanding the scant literature on consensual movements. We offer a comparative study of two cases of this rare and understudied phenomenon. To our knowledge this is the only study looking at consensus movements from the perspective of use of ICTs. Third, our study extends the research on impact of technology-enabled collective action by looking at the combined use of multiple ICTs by organizers of collective action, that is, the ICT ensemble, rather than single ICT. The focus on a single ICT limits the understanding of the current ICT use in collective action situations. By taking this broad conceptualization of the ICT artifact, this study calls attention to possible interrelationships between ICTs which may have positive or negative, unintended effects.

The insights in this paper also have the potential to be useful to the "practice" of collective action. Understanding how the use of ICTs meddles in the organizing of collective action is relevant for an array of organizers who engage in these undertakings, namely organizations from civil society (e.g. associations and non-governmental organizations), interest and advocacy groups, social entrepreneurs, social movements, and online communities (e.g. communities of practice and hobby communities). These insights may be relevant too for practitioners involved in the management of processes of technological innovation, especially radical or disruptive innovations that are path-breaking in an industry or sector. Indeed, according to Hargrave and de Ven (2006), the processes of technological innovation and entrepreneurship are in many ways similar to the collective action processes of social movements because both involve collective mobilization to legitimate either a technical innovation or, in the case of movements, social change.

\subsection{Limitations and Future Work}

There are limitations associated with this research. To begin with, in this research we did not consider the cultural dimensions of the countries in which the cases examined hereto take place. Variability in societal cultures explain "broad tendencies to prefer certain states of affairs over others" (Hofstede, 2001, p. 5), and hence it could be that variations between cases may be explained by differences in the national cultures of Portugal and Estonia. As such, future work should consider this shortcoming and draw on theoretical models of national culture as tools to compare cultures.

A second limitation concerns the strategy of inquiry used in this work. The case study is limited in terms of generalizability of results, and hence our findings are contextual and cannot be extrapolated to a population. Moreover, data collection was done retrospectively. The timespan examined covered the periods of 2007-2013 for Let's Do It and 2009-2013 for Project Let's Cleanup Portugal. Yet, documentation about both cases was collected in 2011 and after, and interview data was collected in 2012 and 2013. Whereas documentation rests as a stable data source, it could be that the interviews were biased by participants' difficulties in recalling events from some time ago. We believe, however, that the conjugation of documentation with interviews provides for a strengthened dataset.

A third limitation concerns the time dimension, which was only superficially leveraged. The movements unfolded at different time periods and thus the availability and prevalence of some ICTs were not the same across the cases. Moreover, different phases (and ICT use) could be delineated within each movement, as shown in Annex 6. But above and beyond this, we simply did not leverage time as a key dimension in our analysis. Analyzing the data longitudinally would undoubtedly shed greater light on how the sequencing of events affected the overall organizing of each movement, and how these events might have exhibited different patterns of influences. 
An additional limitation relates to changes in technologies since we collected our data. Our research examined events that unfolded between 2007 and 2010, and subsequent developments until 2013. The ICTs used then represent the applications and platforms that were popular and widespread at the time. Of course, technologies change at a rapid pace, and new technologies have emerged since. In particular, social media platforms are much more prevalent now. That said, most (but not all) of the ICT leveraged by PLP and LPI are still in use today, and some have evolved towards more modern user interfaces and improved functionality. Technologies are also more integrated now than then, such that ICT ensembles are more common. Thus, whereas today's consensual collective actions may not rely on the exact same set of ICT ensembles that PLP and LPI leveraged, we argue that these differences would not affect how ICT ensembles have the ability to both constrain and enable collective action, nor the importance of the resourcefulness and agency of the collective action's participants.

This research can be extended in different ways. One possibility is studying more cases of consensus movements, including cases of unsuccessful collective action, to unveil patterns of consensual collective action organizing with ICTs in order to thoroughly trace the configurations of this phenomenon. Another possibility is using survey methods to collect data more extensively about the phenomenon. The survey could be based on propositions built from the five aspects of collective action organizing associated with the use of ICTs. Yet one more possibility involves investigating if the findings hold for different types of collective action. The kind of organizing examined here also happens in instances of collective action that are revolutionary and, to some extent, also in collective actions with decelerating production functions (Marwell and Oliver, 1993). Hence, the results of this research beget the question of whether these findings hold, for example, in protest movements, in communities of practice, and in interest groups.

\section{References}

Anduiza, E., Cristancho, C., \& Sabucedo, J. M. (2014). Mobilization through online social networks: the political protest of the indignados in Spain. Information Communication and Society, 17(6), 750-764. https://doi.org/10.1080/1369118X.2013.808360

Bennett, W. L., \& Segerberg, A. (2012). The logic of connective action. Information, Communication \& Society, 15(5), 739-768.

Bennett, W. L., \& Segerberg, A. (2013). The Logic of Connective Action: Digital Media and the Personalization of Contentious Politics. Cambridge University Press.

Biernacki, P., \& Waldorf, D. (1981). Snowballing sampling: Problems and techniques of chain referral sampling. Sociological Methods \& Research, 10(2), 141-163.

Bimber, B, Flanagin, A. J., \& Stohl, C. (2012). Collective Action in Organizations: Interaction and Engagement in an Era of Technological Change. Cambridge University Press.

Bimber, Bruce, Flanagin, A. J., \& Stohl, C. (2005). Reconceptualizing Collective Action in the Contemporary media Environment. Communication Theory, 15(4), 365-388.

Boudreau, M. C., \& Robey, D. (2005). Enacting integrated information technology: A human agency perspective. Organization Science, 16(1), 3-18.

Bucher, T. (2012). Want to be on the top? Algorithmic power and the threat of invisibility on Facebook. New Media \& Society, 14(7), 1164-1180.

Chadwick, A. (2013). The hybrid media system: Politics and power. Oxford University Press. 
Coopman, T. M. (2011). Networks of Dissent: Emergent Forms in Media Based Collective Action. Critical Studies in Media Communication, 28(2), 153-172.

Della Porta, D., \& Diani, M. (2006). Social movements: An introduction (2nd ed.). Wiley-Blackwell.

Diani, M., \& Bison, I. (2004). Organizations, coalitions, and movements. Theory and Society, 33, 281-309.

Earl, J., \& Kimport, K. (2011). Digitally enabled social change: Activism in the internet age. Digitally enabled social change: Activism in the internet age. MIT Press.

Flanagin, A. J., Stohl, C., \& Bimber, B. (2006). Modeling the structure of collective action. Communication Mongraphs, 73(1), 29-54.

Ganz, M. (2002). What is organizing. Social Policy, 33(1), 16-18.

Gens, F. (2013). The 3rd Platform : Enabling Digital Transformation.

George, J., \& Leidner, D. E. (2018). Digital Activism : a Hierarchy of Political Commitment. In 2018 51st Hawaii International Conference on System Sciences (pp. 2299-2308).

Ghobadi, S., \& Clegg, S. (2015). “These days will never be forgotten . ..”: A critical mass approach to online activism. Information and Organization, 25(1), 52-71. https://doi.org/10.1016/j.infoandorg.2014.12.002

Goodchild, M. F. (2007). Citizens as sensors: The world of volunteered geography. GeoJournal, 69(4), 211-221. https://doi.org/10.1007/s10708-007-9111-y

Granovetter, M. (1978). Threshold Models of Collective Behavior. American Journal of Sociology, 83(6), 1420-1443.

Hampton, K. N. (2003). Grieving for a lost network: collective action in a wired suburb. The Information Society, 19(5), 417-428.

Hara, N., \& Youngmin, J. (2007). Internet politics: A comparative analysis of U.S. and South Korea presidential campaigns. First Monday, 12(9), 1.

Hargrave, T. J., \& de Ven, A. H. (2006). A collective action model of institutional innovation. Academy of Management Review, 31(4), 864-888.

Hargrave, T., \& Van De Ven, A. (2006). A Collective Action Model of Innovation Institutional. The Academy of Management Review, 31(4), 864-888. https://doi.org/10.5465/AMR.2006.22527458

Harlow, S., \& Harp, D. (2012). Collective action on the web: A cross-cultural study of social networking sites and online and offline activism in the US and Latin America. Information, Communication \& Society, 15(2), 196-216.

Hofstede, G. H. (2001). Culture's consequences: Comparing values, behaviors, institutions and organizations across nations (2nd editio). Thousand Oaks, CA: Sage.

Holgate, J., \& Simms, M. (2018). The limitations of the theory and practice of mobilization in trade union organizing. Economic and Industrial Democracy, 39(4), 599-616. https://doi.org/10.1177/0143831X18777608

Huang, R., \& Sun, X. (2014). Weibo network, information diffusion and implications for collective 
action in China. Information, Communication \& Society, 17(1), 86-104.

Jenkins, C. J. (1983). Resource Mobilization Theory and the Study of Social Movements. Annual Review of Sociology, 9, 527-553. https://doi.org/10.1016/S0140-6736(09)62087-0

Klein, H K, \& Myers, M. D. (1999). A Set of Principles for Conducting and Evaluating Interpretive Field Studies in Information Systems. MIS Quarterly, 23(1), 67-93.

Klein, Hans K. (1999). Tocqueville in Cyberspace : Using the Internet for Citizen Associations. The Information Society, 15, 213-220.

Lamb, R., \& Davidson, E. (2005). Information and communication technology challenges to scientific professional identity. Information Society, 21(1), 1-24. https://doi.org/10.1080/01972240590895883

Langley, A. (1999). Strategies for theorizing from process data. Academy of Management Review, 24(4), 691-710. https://doi.org/10.5465/AMR.1999.2553248

Leong, C., Pan, S. L., Ractham, P., \& Kaewkitipong, L. (2015). ICT-Enabled Community Empowerment in Crisis Response : Social Media in Thailand Flooding 2011. Jais, 16(3), 174212.

Lev-On, A., \& Hardin, R. (2008). Internet-based collaborations and their political significance. Journal of Information Technology and Politics, 4(2), 5-27. https://doi.org/10.1080/19331680802076074

Lin, W.-Y., \& Dutton, W. H. (2003a). The 'Net' Effect in Politics: The 'Stop the Overlay' Campaign in Los Angeles. Party Politics, 9(1), 124-136.

Lin, W.-Y., \& Dutton, W. H. (2003b). The 'Net' Effect in Politics. Party Politics, 9(1), 124-136. https://doi.org/10.1177/135406880391007

Lofland, J. (1989). Consensus movements: city twinning and derailed dissent in the American eighties. Research in Social Movements, Conflict and Change, 11, 163-196.

Lofland, J. (1993). Polite protesters: The American peace movement of the 1980s. (H. H. Alonso, charles Chatfield, \& L. Kriesberg, Eds.). Syracuse University Press.

Lombardo, C., Zakus, D., \& Skinner, H. (2002). Youth social action: building a global latticework through information and communication technologies. Health Promotion International, 17(4), $363-371$.

Lomicky, C. S., \& Hogg, N. M. (2010). Computer-mediated Communication and Protest: an Examination of Social Movement Activities at Gallaudet, a University for the Deaf. Information, Communication \& Society, 13(5), 674-695.

Lupia, A., \& Sin, G. (2003). Which public goods are endangered?: How evolving communication technologies affect the logic of collective action. Public Choice, 117(3-4), 315-331.

Majchrzak, A., Markus, M. L., \& Wareham, J. (2016). Designing for Digital Transformation: Lessons for Information Systems Research From the Study of ICT and Societal Challenges. MIS Quarterly, 40(2), 267-277. https://doi.org/Article

Markus, M. L. (1987). Toward a "Critical Mass", Theory of Interactive Media Universal Access, Interdependence and Diffusion. Communication Research, 14(5), 491-511. 
Marwell, G., \& Oliver, P. (1993). The critical mass in collective action: a micro-social theory. Cambridge University Press.

McCarthy, J. D., \& Wolfson, M. (1992). Consensus movements, conflict movements, and the cooptation of civic and state infrastructures. In A. D. Morris \& C. M. Mueller (Eds.), Frontiers in social movement theory (pp. 273-297). New Haven, CT: Yale University Press.

McGrath, K., Elbanna, A., Hercheui, M., Panagiotopoulos, P., \& Saad, E. (2012). Exploring the Democratic Potential of Online Social Networking: The Scope and Limitations of eParticipation. Communications of the Association for Information Systems, 30(1), Article 16.

Michaelson, M. (1994). Wangari Maathai and Kenya's Green Belt Movement: Exploring the Evolution and Potentialities of Consensus Movement Mobilization. Social Problems, 41(4), 540-561. https://doi.org/10.3366/ajicl.2011.0005

Micó, J. L., \& Casero-Ripollés, A. (2014). Political activism online: organization and media relations in the case of $15 \mathrm{M}$ in Spain. Information Communication and Society, 17(7), 858871. https://doi.org/10.1080/1369118X.2013.830634

Milan, S. (2015). When algorithms shape collective action: Social media and the dynamics of cloud protesting. Social Media + Society, 1(2), 1-10.

Miles, M. B., \& Huberman, A. M. (1994). Qualitative data analysis: an expanded sourcebook (2nd editio). SAGE Publications.

Mueller, C. M. (1992). Building Social Movements Theory. In A. D. Morris \& C. M. Mueller (Eds.), Frontiers in social movement theory (pp. 3-25). New Haven, CT: Yale University.

Nielsen, R. K. (2009). The labors of internet-assisted activism: Overcommunication, miscommunication, and communicative overload. Journal of Information Technology and Politics, 6(3-4), 267-280. https://doi.org/10.1080/19331680903048840

O’Mahony, S., \& Ferraro, F. (2007). The Emergence Of A Governance Structure In An Open Source Community. Academy of Management Journal, 50(5), 1079-1106.

https://doi.org/10.2307/20159914

Oberschall, A. R. (2001). Action, Collective. In N. J. Smelser \& P. B. Baltes (Eds.), International Encyclopedia of the Social \& Behavioral Sciences (pp. 49-54). Oxford: Pergamon. https://doi.org/http://dx.doi.org/10.1016/B0-08-043076-7/01818-0

Olson, M. (1965). The logic of collective action: public goods and the theory of groups. Cambridge, MA: Harvard University Press.

Ostrom, E. (2002). Property-rights regimes and common goods: a complex link. In A. Heritier (Ed.), Common Goods: Reinventing European and International Governance (pp. 29-58). Rowman \& Littlefield Publishers.

Pierskalla, J. H., \& Hollenbach, F. M. (2013). Technology and Collective Action: The Effect of Cell Phone Coverage on Political Violence in Africa. American Political Science Review, 107(2), 207-224. https://doi.org/10.1017/S0003055413000075

Pikner, T., \& Jauhiainen, J. S. (2014). Dis/appearing waste and afterwards. Geoforum, 54(May 2008), 39-48. https://doi.org/10.1016/j.geoforum.2014.03.009

Römmele, A. (2003). Political parties, party communication and new information and 
communication technologies. Party Politics, 9(1), 7-20.

Santos, F. M. (2012). A positive theory of social entrepreneurship. Journal of Business Ethics, $111(3), 335-351$.

Scheepers, R., \& Middleton, C. (2013). Personal ICT ensembles and ubiquitous information systems environments: Key issues and research implications. Communications of the Association for Information Systems, 33(1), 381-392.

Schwartz, M., \& Paul, S. (1992). Resource mobilization versus the mobilization of people: Why consensus movements cannot be instruments of social change. In A. D. Morris \& C. M. Mueller (Eds.), Frontiers in social movement theory (pp. 205-223). New Haven, CT: Yale University Press.

Selander, L., \& Jarvenpaa, S. L. (2016). Digital action repertoires and transforming a social movement organization. Mis Quarterly, 40(2), 331-352.

Shaw, A., Gerber, E., Zhang, H., Kinnaird, P., Munson, S., Minder, P., ... Monroy-Hernández, A. (2014). Computer supported collective action. Interactions, 21(2), 74-77. https://doi.org/10.1145/2576875

Snow, D. A., Soule, S. A., \& Kriesi, H. (2004). Mapping the Terrain. In D. A. Snow, S. A. Soule, \& H. Kriesi (Eds.), The Blackwell Companion to Social Movements (pp. 3-16). Oxford: Blackwell.

Toyama, K. (2010). Can technology end poverty. Boston Review, 35(6).

Turner, R. H., \& Killian, L. M. (1964). Collective behavior. Prentice-Hall.

Tye, M., Leong, C., Tan, F., Tan, B., \& Khoo, Y. (2018). Social Media for Empowerment in Social Movements: The Case of Malaysia's Grassroots Activism. Communications of the Association for Information Systems, 42(15), 408-430. https://doi.org/10.17705/1CAIS.04215

Vaast, E., Safadi, H., Lapointe, L., \& Negoita, B. (2017). Social media affordances for connective action: an examination of microblogging use during the Gulf of Mexico Oil Spill. Mis Quarterly, 41(4), 1179-1205.

Vasi, I. B. (2006). The New Anti-war Protests and Miscible Mobilizations. Social Movement Studies, 5(2), 137-153.

Walsham, G. (1995). Interpretive case studies in IS research: nature and method. European Journal of Information Systems, 4(2), 74-81.

Wang, C., \& Zhang, P. (2012). The Evolution of Social Commerce: The People, Management, Technology, and Information Dimensions. Communications of the Association for Information Systems, 31(5), 105-127.

Watson-Manheim, M. B., \& Bélanger, F. (2007). Communication media repertoires: dealing with the multiplicity of media choices. MIS Quarterly, 31(2), 267-293.

Winter, S., Berente, N., Howison, J., \& Butler, B. (2014). Beyond the organizational "container": Conceptualizing 21 st century sociotechnical work. Information and Organization, 24(4), 250 269.

Wright, S. (2015). Populism and Downing Street E-petitions: Connective Action, Hybridity, and the 
Changing Nature of Organizing. Political Communication, 32(3), 414-433.

https://doi.org/10.1080/10584609.2014.958256

Young, A. G. (2017). Using ICT for social good: Cultural identity restoration through emancipatory pedagogy. Information Systems Journal, 28, 340-358.

Zheng, Y., \& Yu, A. (2016). Affordances of social media in collective action: the case of Free Lunch for Children in China. Information Systems Journal, 26(3), 289-313. 


\section{Annexes}

Annex 1: Summary literature effects ICTs: https://tinyurl.com/ybuwg738

Annex 2: Online Sources: https://tinyurl.com/y9h9uas4

Annex 3: Interview instrument and demographics: https://tinyurl.com/v8yrexfa

Annex 4: Code books: https://tinyurl.com/val2tvmo

Annex 5: ICTs used with exemplary quotations: https://tinyurl.com/y9hpk7vu

Annex 6: Developmental phases of LDI and PLP: https://tinyurl.com/yd3nqzea

Annex 7: ICTs facilitate and hinder: https://tinyurl.com/y796ucoj

Annex 8: List of new references: https://tinyurl.com/v8ndsapw 